\title{
MORTGAGE TERMINATIONS, HETEROGENEITY AND THE EXERCISE OF MORTGAGE OPTIONS
}

\author{
By YONGHENG Deng, JOHN M. QUIGLEY, AND \\ ROBERT VAN ORDER ${ }^{1}$
}

\begin{abstract}
As applied to the behavior of homeowners with mortgages, option theory predicts that mortgage prepayment or default will be exercised if the call or put option is "in the money" by some specific amount. Our analysis: tests the extent to which the option approach can explain default and prepayment behavior; evaluates the practical importance of modeling both options simultaneously; and models the unobserved heterogeneity of borrowers in the home mortgage market. The paper presents a unified model of the competing risks of mortgage termination by prepayment and default, considering the two hazards as dependent competing risks that are estimated jointly. It also accounts for the unobserved heterogeneity among borrowers, and estimates the unobserved heterogeneity simultaneously with the parameters and baseline hazards associated with prepayment and default functions.

O ur results show that the option model, in its most straightforward version, does a good job of explaining default and prepayment, but it is not enough by itself. The simultaneity of the options is very important empirically in explaining behavior. The results also show that there exists significant heterogeneity among mortgage borrowers. I gnoring this heterogeneity results in serious errors in estimating the prepayment behavior of homeowners.
\end{abstract}

KEYWORDS: Mortgage default, prepayment, dependent competing risks, mortgage pricing.

\section{INTRODUCTION}

THE MORTGAGE MARKET IS QUITE LARGE and is increasing in importance. The outstanding volume of residential mortgages is currently over $\$ 3$ trillion, and volume has doubled in the past decade. In comparison, the stock of outstanding U.S. government debt is currently about $\$ 5$ trillion. A Imost half of the stock of mortgages is held in "mortgage-backed securities," and about half of all new mortgages are "securitized." The rise of securitization, the trading of these securities, and the growing use of mortgage-backed securities as collateral for "derivatives" (e.g., collateralized mortgage obligations) has generated a great deal of interest in the economics of mortgage and mortgage-backed securities.

Pricing mortgage contracts is complicated, primarily by the options available to the borrower to default or to prepay. These options are distinct, but not

\footnotetext{
${ }^{1}$ The authors thank Brian M CCall for providing us the Fortran code used in his $1996 \mathrm{E}$ conometrica paper. The paper benefited from the comments of J ushan Bai, Glenn Sueyoshi, a co-editor and two anonymous referees. The views expressed in this research are those of the authors and do not represent the policies or positions of Freddie M ac. Q uigley's research is supported by the Berkeley Program on Housing and U rban Policy (http://urbanpolicy.berkeley.edu). D eng's initial research was completed at the U niversity of California, Berkeley supported by the Fisher Center for Real Estate and U rban E conomics.
} 
independent. Thus, one cannot calculate accurately the economic value of the default option without considering simultaneously the financial incentive for prepayment. Furthermore, risk preferences and other idiosyncratic differences across borrowers may vary widely. Typically, it is very difficult to measure this heterogeneity explicitly. A ppropriately modeling these prepayment and default risks is crucial to the pricing of mortgages and to understanding the economic behavior of homeowners.

The contingent claims models, developed by Black and Scholes (1973), M erton (1973), Cox, Ingersoll, and Ross (1985), and others, provide a coherent motivation for borrower behavior, and a number of studies have applied this model to the mortgage market. H endershott and $\mathrm{V}$ an Order (1987) and $\mathrm{K}$ au and K eenan (1995) have surveyed much of the literature related to mortgage pricing.

V irtually all previous studies using option models, however, focus on applying them to explain either prepayment or default behavior, but not both. For instance, in the first application of option models to mortgages, Findley and Capozza (1977) analyzed the prepayment options of holders of adjustable-rate and fixed-rate mortgages. Dunn and M CConnell (1981), Buser and $\mathrm{H}$ endershott (1984), and Brennan and Schwartz (1985) used option theory to price callable mortgages, relying on simulation methods. Green and Shoven (1986), Schwartz and Torous (1989), and Quigley and V an Order (1990) provided empirical estimates of option-based prepayment models.

Cunningham and $\mathrm{H}$ endershott (1984) and $\mathrm{E}$ pperson, $\mathrm{K}$ au, Keenan, and $\mathrm{M}$ uller (1985) applied option models to price default risk, modeling default as a put option, and Foster and V an Order (1984) and Quigley and V an Order (1995) estimated default models empirically in an option-based framework. Quercia and Stegman (1992) and V andell (1993) reviewed many of these default models.

A series of papers by Kau, Keenan, M uller, and Epperson (1992, 1995), Kau and Keenan (1996), and Titman and Torous (1989) provided theoretical models that emphasized the importance of the jointness of prepayment and default options. A homeowner who exercises the default option today gives up the option to default in the future, but she also gives up the option to prepay the mortgage. Foster and $V$ an Order (1985) estimated simultaneous models of default and prepayment using data on large pools of FHA loans, and Schwartz and Torous (1993) estimated the joint hazard using a Poisson regression approach and aggregate data. Deng, Quigley, and $V$ an Order (1996) and Deng (1997) were the first to analyze residential mortgage prepayment and default behavior using micro data on the joint choices of individuals. However, the competing risks hazard model common to all these studies ignores the heterogeneity among borrowers. Presumably a substantial number of homeowners are less likely to exercise put and call options on mortgages in the fully rational way predicted by finance theory. A ccounting for this group is potentially important in understanding market behavior and in pricing seasoned mortgages.

In this paper, we present a unified economic model of the competing risks of mortgage termination by prepayment and default. We adopt a proportional hazard framework to analyze these competing risks empirically, using a large sample of individual loans, and we extend the model to analyze unobserved 
heterogeneity. We test three aspects of homeowner behavior in the mortgage market:

1. the extent to which the option approach can explain the default and prepayment behavior of borrowers with single-family mortgages;

2. the importance of modeling both options simultaneously; and

3. the importance of heterogeneity of borrowers in explaining behavior in the market.

We find that:

1. The option model, in its most straightforward version, does a good job of explaining default and prepayment, but it is not enough by itself. Either transactions costs vary a great deal across borrowers, or else some people are simply much worse at exercising options.

2. The simultaneity of the options is very important empirically in explaining behavior. In particular, factors that trigger one option are also important in triggering or foregoing exercise of the other.

3. U nobserved borrower heterogeneity is quite important in accounting for borrower behavior. We allow for heterogeneity by incorporating into the estimation the possibility that there are different sorts of borrowers, some very astute, some quite passive, and others somewhere in between. ${ }^{2}$ We find that heterogeneity is significant. It has important effects on key elasticities explaining behavior, particularly with respect to prepayment.

The paper is organized as follows: Section 2 reviews the application of option models to mortgage terminations. Section 3 discusses the proportional hazard model, specified with competing risks, time-varying covariates and unobserved heterogeneity. Section 4 presents an extensive empirical analysis. Section 5 is a brief conclusion.

\section{MORTGAGE TERMINATIONS AND OPTION PRICING}

Well-informed borrowers in a perfectly competitive market will exercise financial options when they can thereby increase their wealth. In the absence of either transactions costs or reputation costs which reduce credit ratings, and with assumable mortgages (or no exogenous reasons for residential mobility), default and prepayment are essentially financial decisions which can be separated from real (housing) decisions, and the simplest version of the Miller and M odigliani theory of the irrelevance of financial structure holds. ${ }^{3} \mathrm{U}$ nder these conditions, individuals can increase their wealth by defaulting on a mortgage when the market value of the mortgage equals or exceeds the value of the house. Similarly, by prepaying the mortgage when market value equals or exceeds par, they can increase wealth by refinancing. A necessary condition for exercising an option is that it be "in the money," but that is not sufficient. Exercising either option now means giving up the option to exercise both options later. For instance, a borrower whose house price declines below the

\footnotetext{
${ }^{2}$ The unobserved heterogeneity may be attributed to unmeasured house-specific factors (such as unexpected depreciation or appreciation of property values) as well as to borrower tastes or abilities.

${ }^{3}$ See K au, Keenan, M uller, and Epperson (1995) for a recent discussion.
} 
mortgage balance may not default immediately, in part because after the price decline the mortgage has a below-market rate, ${ }^{4}$ but also because by defaulting, the borrower would also lose the option to refinance later on.

While virtually all the recent research on prepayment and default, summarized above, has used option-based models, the underlying theories behind the models differ importantly in the treatment of transactions costs. ${ }^{5}$ F or simplicity, we divide these approaches into polar cases. The first case, M odel I, assumes no transactions costs (see Titman and Torous (1989), Kau, Keenan, Muller, and Epperson (1992)), and "ruthless" exercise of both options. The second case, Model II, emphasizes transactions costs, particularly in exercise of the default option. It is assumed that transactions costs are sufficiently high that default requires, not only negative equity, but also a "trigger event" that forces the borrower to leave the house. Model II also entertains the possibility that there are significant transactions costs involved in prepaying, or else that some borrowers are more astute than others at exercising options (see A rcher, Ling, and McGill (1996)). Finally, Model II also allows the possibility of significant unobserved heterogeneity. Thus the separation between housing and finance decisions is incomplete.

According to Model I, understanding when to exercise either option requires specifying the underlying state variables and the parameters that determine the value of the contract and then deducing the rule for exercise that maximizes borrower wealth. For residential mortgages, the key state variables are interest rates and house values. The value of a mortgage $M(c, r, H, B, k)$ depends upon the coupon rate, $c$, a vector of relevant interest rates, $r$, property value, $H$, the outstanding balance, $B$, the age of the loan, $k$, and some other parameters. W ith continuous time, a standard arbitrage argument is sufficient to derive an equilibrium condition for $M$ (a second order partial differential equation) such that the value of the mortgage equals the risk-adjusted expected present value of its net cash flows.

A ssume that house price changes are continuous with an instantaneous mean $\mu$ and a standard deviation $\sigma_{\mathrm{h}}$. Let $\mathrm{d}$ be the imputed rent payout ("dividend") rate. For simplicity, assume there is only one interest rate, the instantaneous short rate $r$, which determines the yield curve. Let $\theta$ be the mean value of the short rate, $\gamma$ be the rate of convergence for the short rate, $\sigma_{r}$ be the volatility of the short rate, and $\rho$ be the correlation between interest rate changes and house price changes. Then it has been shown ( $\mathrm{Kau}$, Keenan, Muller, and Epperson (1995)) that the value of the mortgage $M$ satisfies

$$
\begin{aligned}
& \frac{1}{2} r \sigma_{r}^{2} \frac{\partial^{2} M}{\partial r^{2}}+\rho \sqrt{r} H \sigma_{r} \sigma_{h} \frac{\partial^{2} M}{\partial r} \partial H \quad+\frac{1}{2} H^{2} \sigma_{h}^{2} \frac{\partial^{2} M}{\partial H^{2}}+\gamma(\theta-r) \frac{\partial M}{\partial r} \\
& +(r-d) H \frac{\partial M}{\partial H}+\frac{\partial M}{\partial \tau}-r M=0 .
\end{aligned}
$$

\footnotetext{
${ }^{4} \mathrm{This}$ is because the mortgage is now riskier, so defaulting and buying back the same house would require paying a higher interest rate or making a larger downpayment.

${ }^{5}$ See K au, Keenan, and Kim (1993) for an explicit discussion of transaction costs.
} 
The value of $M(\cdot)$ and the optimal default and prepayment strategy are determined simultaneously. E quation (1) is consistent with an infinite number of functions $M(\cdot)$. The appropriate function is determined by choosing the optimal level of $r, r^{*}$, and the optimal level of $\mathrm{H}_{1} \mathrm{H}^{*}$, at which to terminate the mortgage through default or prepayment. These are the levels of $r$ and $H$ that minimize $\mathrm{M}$ given equation (1) (see $\mathrm{Kau}, \mathrm{K}$ eenan, Muller, and $\mathrm{Epperson}$ (1995)); these levels are functions of $c, d, B, k$ and the parameters governing the stochastic processes for $r$ and $H$. Due to the jointness of the options, there are two pairs of $\mathrm{r}$ and $\mathrm{H}$ that trigger termination. There are levels of $\mathrm{r}$ that trigger default as well as prepayment, and levels of $\mathrm{H}$ that trigger prepayment as well as default. For instance, a borrower may default at a low enough level of $r$ as a means of prepayment, and a borrower might refinance when equity value has risen because the loan is now safer and would carry a lower interest rate. The estimated probability of default or prepayment is the probability of these levels of $r$ and $\mathrm{H}$ occurring, conditional on the information set of actors in the market and the researchers observing them.

Note that the borrower does not have to solve (1) and the boundary conditions in order to know when to exercise either option. All that is necessary is knowledge of market prices. For instance, for a fixed-rate mortgage, the prepayment option should be exercised whenever the borrower can refinance the loan for the same remaining term at par at a mortgage rate less than the coupon on the current loan or, alternatively when the market value of the mortgage equals (or exceeds) the mortgage balance. D efault should be exercised when the borrower's payments would be lower on a new zero-downpayment loan for the same remaining term, used to purchase the same house. Of course, we on the outside do not observe these market alternatives (and markets are not that complete anyway); this greatly complicates testing the model.

Due to "data limitations," the analyst does not observe the critical levels of house price and the mortgage rate that trigger exercise from the details of the mortgage contract. All that we can hope to observe is the extent to which either option is "in the money." But we cannot even measure directly the extent to which the default option is in the money without data on the course of individual house prices. We can however estimate the probability that the option is in the money, given the initial loan-to-value ratio and the stochastic process for house prices. The analyst can control for the remaining term of the loan, but not for changes in the parameters of the house price or interest rate process. This reality suggests that it is more productive to consider optimal exercise in probabilistic terms and then to test some of the major predictions of Model I: First, the probability of exercise should increase as the option moves further into the money. Second, the probability of exercise should accelerate as the option moves further into the money. Third, because exercising one option means giving up the other option, the extent to which one option is "in the money" should affect the exercise of the other. Thus, for example, the probability of prepayment is a function of the extent to which the default option is in the money. 
M odel I can be extended to address asymmetric information. For instance, we cannot observe directly the parameters governing house price volatilities. This can be a problem if the volatilities vary in a systematic way, for instance if borrowers know more about their own house price volatility than lenders do. Then risky houses might be financed with high loan-to-value (LTV) loans, as borrowers exploit underpriced options. ${ }^{6}$ O ne may control for this by using initial LTV as an explanatory variable in predicting defaults. Similarly, borrowers who expect to move sooner than average will choose to pay fewer "points" up-front; as a result they will have higher than average coupons. A Iso lenders may charge higher rates to borrowers with riskier houses, so that high rates will be associated with higher defaults.

Model I has the great advantage of simplicity.

Model II incorporates transactions costs in a broad sense. It is not simple because transaction costs are complicated and are generally not observable. For instance, different transaction costs across borrowers have been used to explain the observation that the prepayments in mortgage pools tend to be slower than expected and drawn out over time (e.g., see A rcher and Ling (1993), Stanton (1995), $\mathrm{H}$ arding (1997)). This raises the general question of unobserved differences among mortgage borrowers. Whether this empirical finding arises from variations in transaction costs or differences in the astuteness of homeowners exercising options, unobserved heterogeneity means that surviving borrowers are systematically different over time. For instance, surviving borrowers may be increasingly less interest-rate sensitive over time if more astute borrowers refinance first, something of obvious importance in pricing seasoned mortgages.

Transactions costs are more complicated on the default side, particularly if the mortgage is not assumable. A borrower forced to move (e.g., due to divorce or job loss) who cannot have the mortgage assumed has a very short remaining term and may thus default with little negative equity. On the other hand, if there are costs to defaulting, $\mathrm{H}^{*}$ may be lower than $\mathrm{M}$ odel I implies. For these reasons, many researchers (see Q uigley and V an Order (1995) for a discussion) estimate modified option models, which predict that exercise is a function of both "trigger events" like default or divorce and also the extent to which the option is in the money.

We follow Kau and Keenan (1996) who introduce random terminations into the model. These terminations force either a prepayment or a default. If mortgages are not assumable ${ }^{7}$ and there are no (e.g., reputation) costs to default, a random termination will lead to default if the house is worth less than the mortgage balance, and prepayment otherwise. Note that in Model II, it is the par value of the mortgage that is relevant for default. In contrast, in M odel I a borrower is less likely to default when interest rates increase due to the value

\footnotetext{
${ }^{6}$ See Y ezer, Phillips, and Trost (1994) for a discussion.

${ }^{7}$ The empirical analysis below is based on mortgages that were nominally not assumable, but some states forbade exercise of due-on-sale clauses during the observation period, and in any event due on sales clauses were typically not enforced.
} 
of the low-rate mortgage. A ccording to Model II, a borrower who is forced to leave the house does not have the option to keep the mortgage alive. As is the case with prepayments, transactions costs matter, especially if they vary across borrowers or if there are unobservable differences in astuteness among borrowers.

E stimates of default and prepayment are reported below in three stages. First, we estimate proportional hazard models that use as explanatory variables only the extent to which the options are "in the money," in order to test the predictions of M odel I. Second, we add variables that are proxies for information asymmetry (e.g., the original loan-to-value ratio) and trigger events (e.g., unemployment and divorce). Finally, we allow for unobserved heterogeneity and estimate the nonparametric distribution of the unobserved heterogeneity simultaneously with the competing risks of prepayment and default functions.

\section{A COMPETING RISKS MODEL OF MORTGAGE TERMINATION WITH UNOBSERVED HETEROGENEITY}

The proportional hazard model introduced by Cox (Cox and Oakes (1984)), provides a convenient framework for considering the exercise of options empirically and the importance of other trigger events in mortgage terminations.

H an and Hausman (1990), Sueyoshi (1992), and M cCall (1996) (H HSM, for short) suggested a maximum likelihood estimation approach for the proportional hazard model with grouped duration data. The H HSM approach estimates the competing risks simultaneously, accounts for the fact that risks may be correlated, and also that covariates may be time-varying. There is no restriction on the functional form of the baseline hazard (described below). Following H H SM , the competing risks model for mortgage prepayment and default can be derived:

Let $T_{p}$ and $T_{d}$ be the discrete random variables representing the duration of $a$ mortgage until it is terminated by the mortgage holder in the form of prepayment or default, respectively. The joint survivor function conditional on $\eta_{p}, \eta_{d}$, $r, H, Y$, and $X$ can be expressed in the following form:

$$
\begin{aligned}
& S\left(t_{p}, t_{d} \mid r, H, Y, X, \eta_{p}, \eta_{d}\right) \\
&=\exp \left(-\eta_{p} \sum_{k=1}^{t_{p}} \exp \left(\gamma_{p k}+g_{p k}(r, H, Y)+\beta_{p}^{\prime} X\right)\right. \\
&\left.\quad-\eta_{d} \sum_{k=1}^{t_{d}} \exp \left(\gamma_{d k}+g_{d k}(r, H, Y)+\beta_{d}^{\prime} X\right)\right),
\end{aligned}
$$

where $g_{j k}(r, H, Y)$ are time-varying functions of options-related variables, ${ }^{8} r$ and $\mathrm{H}$ are the relevant interest rates and property values, respectively, as discussed in the previous section; $Y$ is a vector of other variables that will be used,

\footnotetext{
${ }^{8}$ The details of the function $g_{j k}(r, H, Y)$ are specified in the following section and the A ppendix.
} 
together with $r$ and $H$, to estimate the market values of the options empirically; $X$ is a vector of other non-option-related variables, which may include indicators reflecting a borrower's credit risk or financial strength, as well as other trigger events, such as unemployment and divorce. To simplify the notation, we suppress the time-varying subscripts for $r, H, Y$, and $X . \gamma_{j k}$ are parameters of the baseline function which may be estimated nonparametrically, following $\mathrm{H}$ an and H ausman (1990):

$$
\gamma_{j k}=\log \left[\int_{k-1}^{k} h_{0 j}(t) d t\right], \quad j=p, d .
$$

$\eta_{\mathrm{p}}$ and $\eta_{\mathrm{d}}$ are unobserved heterogeneities associated with the hazard functions for prepayment and default respectively.

We allow for the possibility that the population of mortgage borrowers consists of $M$ distinct groups. The joint distribution of the unobservables $\left(\eta_{p}, \eta_{d}\right)$ is modeled by assuming that these distinct, but unobserved types of individuals, $\mathrm{m}=1,2, \ldots, \mathrm{M}$ (an individual in group $\mathrm{m}$ is characterized by the doublet of location parameters $\left.\left(\eta_{\mathrm{pm}}, \eta_{\mathrm{dm}}\right)\right)$, occur in the population with relative frequency $p_{m}, m=1,2, \ldots, M$.

Due to the nature of the competing risks between prepayment and default, only the duration associated with the type that terminates first is observed, i.e. $\mathrm{t}=\min \left(\mathrm{t}_{\mathrm{p}}, \mathrm{t}_{\mathrm{d}}\right)$. D efine $\mathrm{F}_{\mathrm{p}}\left(\mathrm{k} \mid \eta_{\mathrm{p}}, \eta_{\mathrm{d}}\right)$ as the probability of mortgage termination by prepayment in period $k, F_{d}\left(k \mid \eta_{d}, \eta_{d}\right)$ as the probability of mortgage termination by default in period $k, \mathrm{~F}_{\mathrm{u}}\left(\mathrm{k} \mid \eta_{\mathrm{p}}, \eta_{\mathrm{d}}\right)$ as the probability of mortgage termination in period $\mathrm{k}$ but information on the cause of the termination is missing, and $\mathrm{F}_{\mathrm{c}}\left(\mathrm{k} \mid \eta_{\mathrm{p}}, \eta_{\mathrm{d}}\right)$ as the probability that mortgage duration data are censored in period $\mathrm{k}$ due to the ending of the data collecting period.

Following M cCall (1996), these probabilities can be expressed as

$$
\begin{aligned}
\mathrm{F}_{\mathrm{p}}\left(\mathrm{k} \mid \eta_{\mathrm{p}}, \eta_{\mathrm{d}}\right)= & \mathrm{S}\left(\mathrm{k}, \mathrm{k} \mid \eta_{\mathrm{p}}, \eta_{\mathrm{d}}\right)-\mathrm{S}\left(\mathrm{k}+1, \mathrm{k} \mid \eta_{\mathrm{p}}, \eta_{\mathrm{d}}\right)-\frac{1}{2} \mathrm{~S}\left(\mathrm{k}, \mathrm{k} \mid \eta_{\mathrm{p}}, \eta_{\mathrm{d}}\right) \\
& +\mathrm{S}\left(\mathrm{k}+1, \mathrm{k}+1 \mid \eta_{\mathrm{p}}, \eta_{\mathrm{d}}\right)-\mathrm{S}\left(\mathrm{k}, \mathrm{k}+1 \mid \eta_{\mathrm{p}}, \eta_{\mathrm{d}}\right) \\
& -\mathrm{S}\left(\mathrm{k}+1, \mathrm{k} \mid \eta_{\mathrm{p}}, \eta_{\mathrm{d}}\right)
\end{aligned}
$$

$$
\begin{aligned}
\mathrm{F}_{\mathrm{d}}\left(\mathrm{k} \mid \eta_{\mathrm{p}}, \eta_{\mathrm{d}}\right)= & \mathrm{S}\left(\mathrm{k}, \mathrm{k} \mid \eta_{\mathrm{p}}, \eta_{\mathrm{d}}\right)-\mathrm{S}\left(\mathrm{k}, \mathrm{k}+1 \mid \eta_{\mathrm{p}}, \eta_{\mathrm{d}}\right)-\frac{1}{2} \mathrm{~S}\left(\mathrm{k}, \mathrm{k} \mid \eta_{\mathrm{p}}, \eta_{\mathrm{d}}\right) \\
& +\mathrm{S}\left(\mathrm{k}+1, \mathrm{k}+1 \mid \eta_{\mathrm{p}}, \eta_{\mathrm{d}}\right)-\mathrm{S}\left(\mathrm{k}, \mathrm{k}+1 \mid \eta_{\mathrm{p}}, \eta_{\mathrm{d}}\right) \\
& -\mathrm{S}\left(\mathrm{k}+1, \mathrm{k} \mid \eta_{\mathrm{p}}, \eta_{\mathrm{d}}\right),
\end{aligned}
$$

$$
\mathrm{F}_{\mathrm{u}}\left(\mathrm{k} \mid \eta_{\mathrm{p}}, \eta_{\mathrm{d}}\right)=\mathrm{S}\left(\mathrm{k}, \mathrm{k} \mid \eta_{\mathrm{p}}, \eta_{\mathrm{d}}\right)-\mathrm{S}\left(\mathrm{k}+1, \mathrm{k}+1 \mid \eta_{\mathrm{p}}, \eta_{\mathrm{d}}\right) \text {, }
$$


and

$$
\mathrm{F}_{\mathrm{c}}\left(\mathrm{k} \mid \eta_{\mathrm{p}}, \eta_{\mathrm{d}}\right)=\mathrm{S}\left(\mathrm{k}, \mathrm{k} \mid \eta_{\mathrm{p}}, \eta_{\mathrm{d}}\right),
$$

where the dependence of these functions on $r, H, Y$, and $X$ has been omitted for notational simplicity.

The unconditional probability is given by

$$
F_{j}(k)=\sum_{m=1}^{M} p_{m} F_{j}\left(k \mid \eta_{p m}, \eta_{d m}\right), \quad j=p, d, u, c .
$$

The log likelihood function of the competing risks model is given by

$$
\begin{aligned}
\log \mathrm{L}= & \sum_{\mathrm{i}=1}^{\mathrm{N}} \delta_{\mathrm{pi}} \log \left(\mathrm{F}_{\mathrm{p}}\left(\mathrm{K}_{\mathrm{i}}\right)\right)+\delta_{\mathrm{di}} \log \left(\mathrm{F}_{\mathrm{d}}\left(\mathrm{K}_{\mathrm{i}}\right)\right)+\delta_{\mathrm{ui}} \log \left(\mathrm{F}_{\mathrm{u}}\left(\mathrm{K}_{\mathrm{i}}\right)\right) \\
& +\delta_{\mathrm{ci}} \log \left(\mathrm{F}_{\mathrm{c}}\left(\mathrm{K}_{\mathrm{i}}\right)\right)
\end{aligned}
$$

where $\delta_{\mathrm{ji}}, \mathrm{j}=\mathrm{p}, \mathrm{d}, \mathrm{u}, \mathrm{c}$ are indicator variables that take value one if the ith loan is terminated by prepayment, default, unknown type, or censoring, respectively, and take a value of zero otherwise.

\section{THE EMPIRICAL ANALYSIS}

The empirical analysis is based upon individual mortgage history data maintained by the Federal $\mathrm{H}$ ome Loan M ortgage Corporation (Freddie M ac). The data base contains $1,489,372$ observations on single family mortgage loans issued between 1976 to 1983 and purchased by Freddie Mac. All are fixed-rate, level-payment, fully-amortized loans, most of them with thirty-year terms. The mortgage history period ends in the first quarter of 1992. For each mortgage loan, the available information includes the year and month of origination and termination (if it has been closed), indicators of prepayment or default, the purchase price of the property, the original loan amount, the initial loan-to-value ratio, the mortgage contract interest rate, the monthly principal and interest payment, the state, the region, and the major metropolitan area in which the property is located. For the mortgage default and prepayment model, censored observations include all matured loans as well as the loans active at the end of the period.

The analysis is confined to mortgage loans issued for owner occupancy, and includes only those loans that were either closed or still active at the first quarter of 1992. The analysis is confined to loans issued in 30 major metropolitan areas (M SA s) - a total of 447,042 observations. L oans are observed in each quarter from the quarter of origination through the quarter of termination, maturation, or through 1992:I for active loans.

The key variables are those measuring the extent to which the put and call options are in the money. To value the call option, the current mortgage interest 
rate and the initial contract terms are sufficient. We compute a variable "Call_Option" measuring the ratio of the present discounted value of the unpaid mortgage balance at the current quarterly mortgage interest rate ${ }^{9}$ relative to the value discounted at the contract interest rate. ${ }^{10}$

To value the put option analogously, we would measure the market value of each house quarterly and compute homeowner equity quarterly. 0 bviously, we do not observe the course of price variation for individual houses in the sample. We do, however, have access to a large sample of repeat (or paired) sales of single family houses in these 30 metropolitan areas (M SA s). This information is sufficient to estimate a weighted repeat sales house price index (WRS) separately for each of the 30 MSA s. The WR S index provides estimates of the course of house prices in each metropolitan area. It also provides an estimate of the variance in price for each house in the sample, by metropolitan area and elapsed time since purchase. ${ }^{11}$

Estimates of the mean and variance of individual house prices, together with the unpaid mortgage balance (computed from the contract terms), permit us to estimate the distribution of homeowner equity quarterly for each observation. In particular, the variable "Put_Option" measures the probability that homeowner equity is negative, i.e., the probability that the put option is in the money. ${ }^{12}$

As proxies for other "trigger events," we include measures of the quarterly unemployment rate and the annual divorce rate by state. ${ }^{13}$

Figure 1 summarizes the raw data used in the empirical analysis described below. Panel A displays the average (Kaplan-Meier) conditional prepayment rates, separately by the loan-to-value ratio at origination (LTV), as a function of duration. Conditional prepayment rates are slightly higher for higher LTV loans. $R$ ates increase substantially after the first fifteen quarters. Panel $C$ of Figure 1 displays average (Kaplan-M eier) conditional default rates by LTV. Note again that default rates increase substantially after about fifteen quarters. Note also that the default rates vary substantially by initial LTV. Default rates for 90 percent LTV loans are four or five times higher than default rates for 80 to 90 percent LTV loans. The default rates for these latter loans are, in turn, about twice as high as for those with LTV below 80 percent.

Finally, note that conditional default rates are quite low. Even for the riskiest class of loans, conditional default rates are no higher than two in a thousand in

\footnotetext{
${ }^{9} \mathrm{The}$ rate used is the average interest rate charged by lenders on new first mortgages reported by Freddie Mac's market survey. This mortgage interest rate varies by quarter across five major US regions.

${ }^{10}$ See A ppendix A for the specification of the "Call_Option" variable.

${ }^{11}$ See $A$ ppendix $B$ for the specification of the house price indices and their volatilities.

${ }^{12}$ See A ppendix A for the specification of the "Put_Option" variable.

${ }^{13}$ State unemployment data are reported in various issues of: U S D epartment of Labor, "E mployment and Unemployment in States and Local Areas (Monthly)" and in the "Monthly Labor Review." State divorce data are reported in various issues of U.S. National Center for Health Statistics, "Vital Statistics of the United States, Volume III, Marriage and Divorce," and in "Statistical Abstract of the U.S."
} 


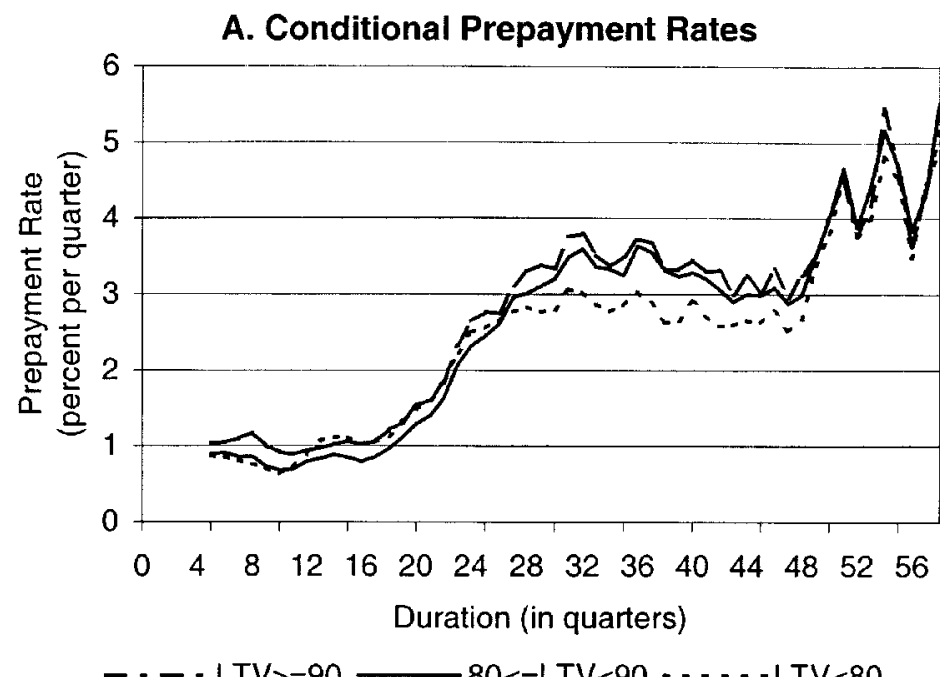

B. Cumulative Prepayment Rates

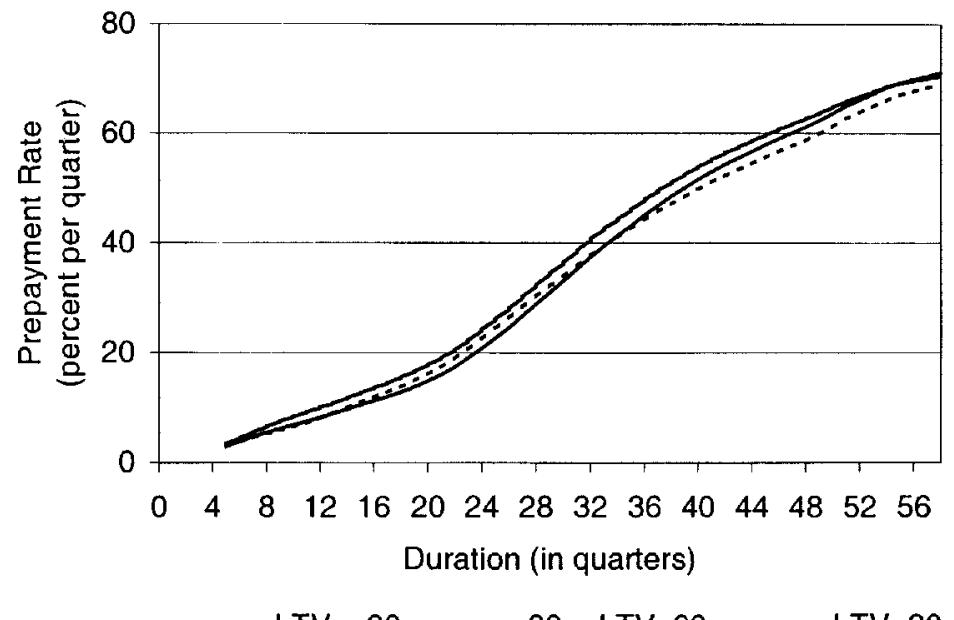

FIGURE 1

any quarter. Residential mortgages are relatively safe investments, and the period as a whole was one of generally rising house prices (keeping the put option out of the money).

Table I presents the means and standard deviations of the explanatory variables measured at origination and termination of the mortgage loans. The 


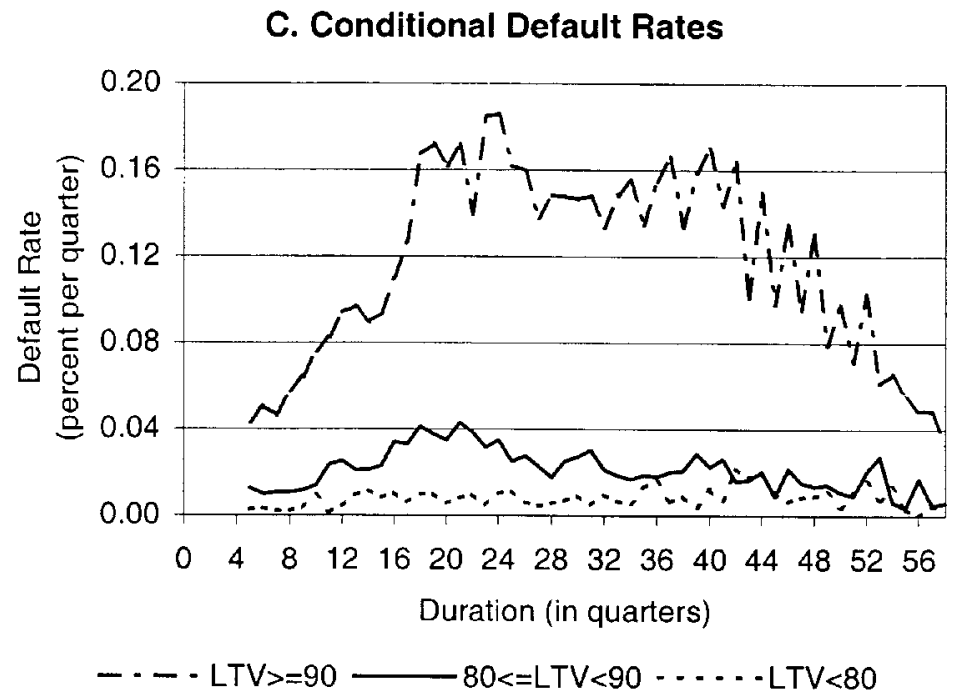

\section{Cumulative Default Rates}

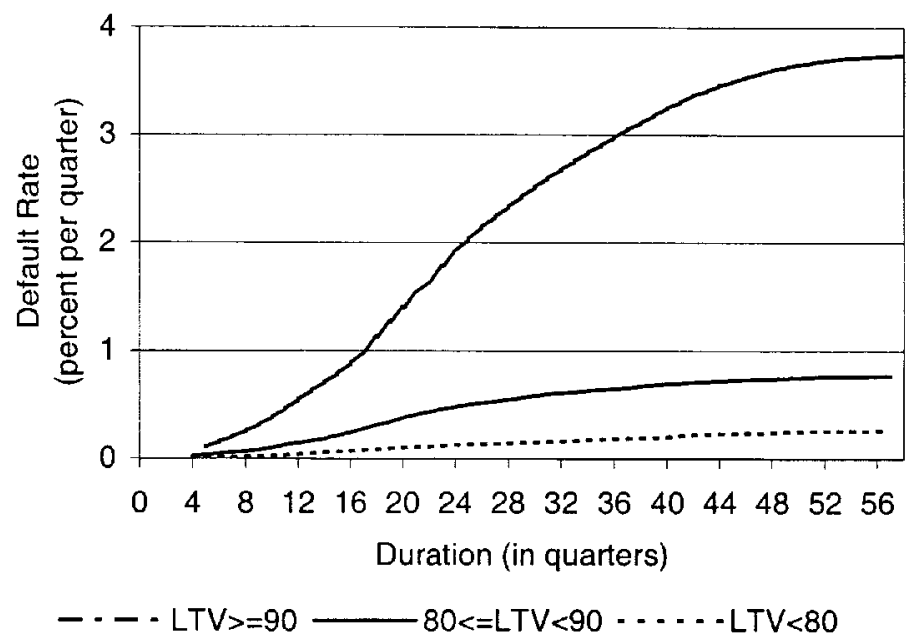

FIgURE 1 (Continued)

mean value of the prepayment option, "Call_Option," is "out of the money" when mortgages were originated, but is much less so when the mortgages were terminated (presumably reflecting the fact that most prepayments arise because homeowners move for other reasons; see Q uigley (1987)). The mean value of the probability of negative equity, "Put_Option," is quite low in general when mortgages were originated. The initial probability is about 0.007 for those 
TABLE I

Descriptive Statistics on Mortgage Loans Mean Values at Origination and Termination

\begin{tabular}{|c|c|c|c|c|c|c|}
\hline \multirow[b]{2}{*}{ V ariable } & \multicolumn{4}{|c|}{ At Origination } & \multicolumn{2}{|c|}{ At Termination } \\
\hline & All Loans & Prepaid & Defaulted & Other ${ }^{a}$ & Prepaid & D efaulted \\
\hline $\begin{array}{l}\text { Call O ption (fraction of } \\
\text { contract value) }\end{array}$ & $\begin{array}{r}-0.0529 \\
(0.0067)\end{array}$ & $\begin{array}{r}-0.0559 \\
(0.0073)\end{array}$ & $\begin{array}{r}-0.0746 \\
(0.0102)\end{array}$ & $\begin{array}{c}-0.0427 \\
(0.0045)\end{array}$ & $\begin{array}{r}-0.0265 \\
(0.0329)\end{array}$ & $\begin{array}{l}0.0321 \\
(0.0273)\end{array}$ \\
\hline $\begin{array}{l}\text { Put O ption (probability } \\
\text { of negative equity) }\end{array}$ & $\begin{array}{c}0.0072 \\
(0.0005)\end{array}$ & $\begin{array}{c}0.0069 \\
(0.0005)\end{array}$ & $\begin{array}{c}0.0371 \\
(0.0030)\end{array}$ & $\begin{array}{c}0.0062 \\
(0.0004)\end{array}$ & $\begin{array}{c}0.0067 \\
(0.0013)\end{array}$ & $\begin{array}{r}0.0918 \\
(0.0283)\end{array}$ \\
\hline $\begin{array}{l}\text { Squared Term of Call } \\
\text { Option }\end{array}$ & $\begin{array}{c}0.0095 \\
(0.0005)\end{array}$ & $\begin{array}{c}0.0104 \\
(0.0006)\end{array}$ & $\begin{array}{c}0.0157 \\
(0.0009)\end{array}$ & $\begin{array}{c}0.0063 \\
(0.0004)\end{array}$ & $\begin{array}{c}0.0336 \\
(0.0035)\end{array}$ & $\begin{array}{c}0.0283 \\
(0.0021)\end{array}$ \\
\hline $\begin{array}{l}\text { Squared Term of Put } \\
\text { Option }\end{array}$ & $\begin{array}{c}0.0006 \\
(0.0000)\end{array}$ & $\begin{array}{c}0.0005 \\
(0.0000)\end{array}$ & $\begin{array}{c}0.0044 \\
(0.0002)\end{array}$ & $\begin{array}{c}0.0004 \\
(0.0000)\end{array}$ & $\begin{array}{c}0.0014 \\
(0.0005)\end{array}$ & $\begin{array}{c}0.0367 \\
(0.0162)\end{array}$ \\
\hline $\begin{array}{l}\text { State D ivorce R ate } \\
\quad \text { (percent) }\end{array}$ & $\begin{array}{c}5.4486 \\
(0.8015)\end{array}$ & $\begin{array}{l}5.4448 \\
(0.7659)\end{array}$ & $\begin{array}{c}5.8430 \\
(0.5083)\end{array}$ & $\begin{array}{c}5.4349 \\
(0.9105)\end{array}$ & $\begin{array}{r}4.8635 \\
(0.5585)\end{array}$ & $\begin{array}{l}5.2587 \\
(0.3650)\end{array}$ \\
\hline $\begin{array}{l}\text { State } U \text { nemployment } \\
\text { R ate (percent) }\end{array}$ & $\begin{array}{c}6.8605 \\
(2.4960)\end{array}$ & $\begin{array}{c}6.9609 \\
(2.5356)\end{array}$ & $\begin{array}{r}6.88165 \\
(3.6764)\end{array}$ & $\begin{array}{c}6.5648 \\
(2.1951)\end{array}$ & $\begin{array}{l}6.6796 \\
(2.8578)\end{array}$ & $\begin{array}{r}7.6085 \\
(3.5006)\end{array}$ \\
\hline $\begin{array}{l}\text { Initial Loan-To-V alue } \\
\text { Ratio (LTV) }\end{array}$ & $\begin{array}{c}0.7657 \\
(0.0240)\end{array}$ & $\begin{array}{c}0.7649 \\
(0.0240)\end{array}$ & $\begin{array}{c}0.8900 \\
(0.0060)\end{array}$ & $\begin{array}{c}0.7597 \\
(0.0239)\end{array}$ & - & - \\
\hline No. of O bservations & 22,294 & 16,402 & 363 & 5,529 & 16,402 & 363 \\
\hline
\end{tabular}

NOTE: Standard deviations are in parentheses.

${ }^{a}$ Other includes matured mortgages as well as those outstanding at the end of the observation period.

mortgages that were ultimately terminated by prepayment, but the initial probability of negative equity is much larger for those loans that were ultimately terminated by default. In part, this difference reflects the much higher initial loan-to-value ratios of those mortgages ultimately terminated by default. Finally, at termination the defaulted mortgages are associated with substantially higher average unemployment rates and divorce rates than those mortgages terminated by prepayment.

Table II presents the means and standard deviations of the explanatory variables measured at termination of the mortgage loans, separately by initial LTV categories. The differences in the values of the call option across LTV groups are insignificant. However, the put option values are significantly different among different LTV groups, i.e., higher LTV ratios at origination are associated with higher probabilities of negative equity at the termination of the mortgage loans.

Table II also presents cumulative prepayment and default rates at different ages of mortgage life by initial LTV categories. The differences in cumulative prepayment rates among different LTV categories are relatively small, but a higher initial LTV is strongly associated with a higher cumulative default rate. This strong association persists during different stages of the mortgage life.

\subsection{Specifications and Results}

Table III presents maximum likelihood estimates of the parameters of models of competing risks of mortgage prepayment and default. Estimates in this table 
TABLE II

Descriptive Statistics on Mortgage Loans

Mean Valuesat Termination a and Cumulative Rates by Initial LTV Category

\begin{tabular}{|c|c|c|c|c|c|}
\hline Variable & All Loans & $\mathrm{LTV} \leq 75$ & $75<\mathrm{LTV} \leq 80$ & $80<\mathrm{LTV} \leq 90$ & $L T V \geq 90$ \\
\hline \multicolumn{6}{|l|}{ A. M ean $V$ alue } \\
\hline $\begin{array}{l}\text { Call O ption (fraction of } \\
\text { contract value) }\end{array}$ & $\begin{array}{r}-0.0057 \\
(0.0270)\end{array}$ & $\begin{array}{c}0.0000 \\
(0.0267)\end{array}$ & $\begin{array}{r}-0.0161 \\
(0.0259)\end{array}$ & $\begin{array}{r}-0.0030 \\
(0.0273)\end{array}$ & $\begin{array}{r}0.0040 \\
(0.0296)\end{array}$ \\
\hline $\begin{array}{l}\text { Put O ption (probability } \\
\text { of negative equity) }\end{array}$ & $\begin{array}{c}0.0067 \\
(0.0016)\end{array}$ & $\begin{array}{c}0.0006 \\
(0.0002)\end{array}$ & $\begin{array}{c}0.0019 \\
(0.0001)\end{array}$ & $\begin{array}{c}0.0105 \\
(0.0016)\end{array}$ & $\begin{array}{c}0.0334 \\
(0.0100)\end{array}$ \\
\hline $\begin{array}{l}\text { Squared Term of Call } \\
\text { Option }\end{array}$ & $\begin{array}{c}0.0270 \\
(0.0028)\end{array}$ & $\begin{array}{c}0.0267 \\
(0.0028)\end{array}$ & $\begin{array}{c}0.0262 \\
(0.0028)\end{array}$ & $\begin{array}{c}0.0273 \\
(0.0028)\end{array}$ & $\begin{array}{c}0.0297 \\
(0.0030)\end{array}$ \\
\hline $\begin{array}{l}\text { Squared Term of Put } \\
\text { Option }\end{array}$ & $\begin{array}{l}0.0016 \\
(0.0007)\end{array}$ & $\begin{array}{c}0.0002 \\
(0.0000)\end{array}$ & $\begin{array}{c}0.0001 \\
(0.0000)\end{array}$ & $\begin{array}{l}0.0017 \\
(0.0005)\end{array}$ & $\begin{array}{r}0.0111 \\
(0.0051)\end{array}$ \\
\hline $\begin{array}{l}\text { State U nemployment } \\
\text { R ate (percent) }\end{array}$ & $\begin{array}{c}7.1593 \\
(3.2006)\end{array}$ & $\begin{array}{c}7.2773 \\
(3.3740)\end{array}$ & $\begin{array}{c}7.2123 \\
(3.1218)\end{array}$ & $\begin{array}{c}7.1006 \\
(3.1085)\end{array}$ & $\begin{array}{r}6.7308 \\
(2.9797)\end{array}$ \\
\hline $\begin{array}{l}\text { State Divorce R ate } \\
\text { (percent) }\end{array}$ & $\begin{array}{c}4.8068 \\
(0.6165)\end{array}$ & $\begin{array}{c}4.7378 \\
(0.6066)\end{array}$ & $\begin{array}{c}4.8044 \\
(0.5152)\end{array}$ & $\begin{array}{c}4.8498 \\
(0.5878)\end{array}$ & $\begin{array}{r}4.9498 \\
(0.8902)\end{array}$ \\
\hline \multicolumn{6}{|l|}{ B. Cumulative $R$ ates } \\
\hline $\begin{array}{l}\text { Cumulative Prepayment } \\
\text { in } 5 \text { years (percent) }\end{array}$ & 18.8 & 19.8 & 17.0 & 18.6 & 21.7 \\
\hline $\begin{array}{l}\text { Cumulative Prepayment } \\
\text { in } 10 \text { years (percent) }\end{array}$ & 57.0 & 55.6 & 56.7 & 60.2 & 55.8 \\
\hline $\begin{array}{l}\text { Cumulative Prepayment } \\
\text { in } 15 \text { years (percent) }\end{array}$ & 73.2 & 72.6 & 74.4 & 75.0 & 67.7 \\
\hline $\begin{array}{l}\text { Cumulative D efault } \\
\text { in } 5 \text { years (percent) }\end{array}$ & 0.7 & 0.1 & 0.4 & 1.4 & 1.8 \\
\hline $\begin{array}{l}\text { Cumulative D efault } \\
\text { in } 10 \text { years (percent) }\end{array}$ & 1.4 & 0.2 & 0.8 & 2.6 & 5.1 \\
\hline $\begin{array}{l}\text { Cumulative D efault } \\
\text { in } 15 \text { years (percent) }\end{array}$ & 1.6 & 0.2 & 0.8 & 2.8 & 6.1 \\
\hline No. of O bservations & 22,294 & 7,420 & 7,542 & 4,988 & 2,344 \\
\hline
\end{tabular}

assume prepayment and default risks are interdependent. However, the models do not address unobserved heterogeneity.

Model 1 in Table III tests the "ruthless" model, i.e., Model I, as described in Section 2. The model includes only measures of the financial value of the prepayment and default options. The results provide support for the option theory in that the prepayment hazard increases when the call option is in the money, and a higher probability of negative equity increases the default hazard and reduces the prepayment hazard. The results also indicate that the estimated second order effect of the prepayment option is significant and positive, suggesting that after the interest rate drops below the critical point $r^{*}$ as discussed in Section 2, the prepayment speed increases substantially. ${ }^{14}$

\footnotetext{
${ }^{14} \mathrm{H}$ owever, that is not the case in the default function for which the second term is essentially zero. It is also the case that low interest rates (a high value of Call_O ption) lead to negative equity. We have estimated all the models with Put_Option computed from both market and par value of the mortgages and found no significant changes in any parameter estimates. See A ppendix A.
} 
TABLE III

Maximum Likelihood Estimates for Competing Risks of Mortgage Prepayment and Default Without Heterogeneity

\begin{tabular}{|c|c|c|c|c|}
\hline & \multicolumn{2}{|c|}{ M odel 1} & \multicolumn{2}{|c|}{ Model 2} \\
\hline & Prepayment & Default & Prepayment & D efault \\
\hline $\begin{array}{l}\text { Call O ption (fraction of } \\
\text { contract value) }\end{array}$ & $\begin{array}{r}4.795 \\
(124.84)\end{array}$ & $\begin{array}{r}6.283 \\
(20.10)\end{array}$ & $\begin{array}{r}4.837 \\
(118.61)\end{array}$ & $\begin{array}{r}6.768 \\
(19.78)\end{array}$ \\
\hline $\begin{array}{l}\text { Put O ption (probability } \\
\text { of negative equity) }\end{array}$ & $\begin{array}{r}-3.607 \\
(8.76)\end{array}$ & $\begin{array}{l}15.286 \\
(19.79)\end{array}$ & $\begin{array}{r}-3.495 \\
(7.79)\end{array}$ & $\begin{array}{l}8.662 \\
(9.19)\end{array}$ \\
\hline $\begin{array}{l}\text { Squared Term of Call } \\
\text { Option }\end{array}$ & $\begin{array}{r}2.663 \\
(20.76)\end{array}$ & $\begin{array}{c}-0.359 \\
(0.32)\end{array}$ & $\begin{array}{r}2.695 \\
(20.49)\end{array}$ & $\begin{array}{r}0.236 \\
(0.20)\end{array}$ \\
\hline Squared Term of Put & 3.476 & -16.343 & 3.373 & -9.199 \\
\hline $\begin{array}{c}\text { Option } \\
0.6<\text { LTV } \leq 0.75\end{array}$ & $(5.45)$ & (14.76) & $\begin{array}{r}(5.00) \\
0.035\end{array}$ & $\begin{array}{r}(7.42) \\
1.384\end{array}$ \\
\hline $0.75<$ LTV $\leq 0.8$ & & & $\begin{array}{r}0.060 \\
(2.69)\end{array}$ & $\begin{array}{r}2.231 \\
(3.75)\end{array}$ \\
\hline $0.8<\mathrm{LTV} \leq 0.9$ & & & $\begin{array}{r}0.077 \\
(3.19)\end{array}$ & $\begin{array}{l}3.146 \\
(5.36)\end{array}$ \\
\hline LTV $>0.9$ & & & $\begin{array}{c}-0.056 \\
(1.89)\end{array}$ & $\begin{array}{r}3.518 \\
(5.98)\end{array}$ \\
\hline State U nemployment & & & -0.007 & 0.097 \\
\hline$R$ ate (percent) & & & $(1.37)$ & $(3.00)$ \\
\hline $\begin{array}{l}\text { State D ivorce R ate } \\
\text { (percent) }\end{array}$ & & & $\begin{array}{l}0.032 \\
(3.10)\end{array}$ & $\begin{array}{r}0.415 \\
(4.59)\end{array}$ \\
\hline LOC & $\begin{array}{r}1.330 \\
(111.42)\end{array}$ & $\begin{array}{r}2.517 \\
(13.28)\end{array}$ & $\begin{array}{r}0.803 \\
(18.45)\end{array}$ & $\begin{array}{r}0.059 \\
(1.25)\end{array}$ \\
\hline Log Likelihood & \multicolumn{2}{|c|}{$-74,981$} & \multicolumn{2}{|c|}{$-74,813$} \\
\hline
\end{tabular}

NOTE: $t$ ratios are in parentheses. All models are estimated by $M L$ approach with flexible baseline hazard function. Prepayment and default functions are considered as correlated competing risks and they are estimated jointly. Restrictions of homogeneous error terms were imposed during the maximum likelihood estimation. $L O C$ is the location parameter of the error term.

Model 2 in Table III extends the "ruthless" model by adding asymmetric information and the trigger event variables, such as original LTV category, unemployment, and divorce. The results show that financial motivation is still of paramount importance governing the prepayment and default behavior. In addition, the results suggest that borrowers' willingness to exercise financial options may be triggered or hindered by other events. For example, it suggests that higher default risks are associated with higher original LTV's. This is consistent with the argument in Section 2 (see Y ezer, Phillips, and Trost (1994)) that information is asymmetric, and riskier borrowers choose high LTV loans. The prepayment risk increases slightly as original LTV increases, except for the highest LTV category. For loans with original LTV over 90 percent, the prepayment risk is reduced. The estimates also show that unemployment and divorce are positive and highly significant in the default function, reflecting 
liquidity constraints and the effect of trigger events upon the exercise of put options. $^{15}$

Table IV reports the maximum likelihood estimates of the interdependent competing risks of mortgage prepayment and default with unobserved heterogeneity as specified in Section 3. In Models 3 and 4, we assume that there are two populations among borrowers. The difference in riskiness between these two groups may be attributed to unmeasured house-specific factors (such as unexpected depreciation or appreciation in property values) as well as to borrower tastes or abilities. Each borrower may either belong to the high risk group or the low risk group. We do not observe directly the group to which an individual borrower belongs. Since unobserved heterogeneity may be correlated with the errors in the competing risks of prepayment and default hazard functions, we estimate the distribution of the unobserved heterogeneity jointly with the competing risks of prepayment and default hazard functions.

Model 3 reestimates the "ruthless" model reported in Table III. The estimates still provide support for the predictions of option theory: the prepayment hazard increases when the call option is in the money; similarly a higher probability of negative equity increases the default hazard and reduces the prepayment hazard. However, the marginal effect of the prepayment option, "Call_Option," reported in Table IV increases substantially-by about 20 percent compared to that reported in Table III. This suggests that estimating the prepayment risk without accounting for heterogeneity leads to a substantial underestimate of option-driven prepayment behavior. The estimates also show that there is a substantial and statistically significant difference between the two groups in exercising the prepayment option. The borrowers in the high risk group are about 4.73 times riskier than the borrowers in the low risk group in terms of prepayment risks $(1.972 / 0.417)$. H owever, there is almost no difference between the two groups in terms of default risks $(2.577 / 2.403)$.

Model 4 reestimates Model 2 reported in Table III. In general, the importance of the option values reported in Model 3 is confirmed. In addition, the unemployment variable is negative and highly significant in the prepayment function -indicating that liquidity constraints (which make refinancing more difficult for unemployed and divorced households) keep them from exercising in-the-money call options. It seems clear that the original LTV, unemployment, and divorce may trigger or hinder the borrower's willingness to exercise the options. These findings are analogous to those noted in Model 2 in Table III. Note that, in Model 4, after including trigger event variables explicitly in the prepayment and default hazard function, the estimated heterogeneity becomes less significant relative to its importance in Model 3. Nonetheless, we still find

\footnotetext{
${ }^{15} \mathrm{We}$ also added the difference between the coupon on the mortgage and the average coupon rate during the quarter in which the loan was originated to test (following the argument in Section 2) whether high coupon loans prepay faster and/or default more. We found both signs to be positive, but not statistically significant; as a result we do not include relative coupon rate in any of the results presented in the tables.
} 
TABLE IV

MAximum Likelihood Estimates for Competing Risks of Mortgage Prepayment and

DEFAULT WITH UNOBSERVED HETEROGENEITY

\begin{tabular}{|c|c|c|c|c|c|c|c|c|}
\hline & \multicolumn{2}{|c|}{ M odel 3} & \multicolumn{2}{|c|}{ M odel 4} & \multicolumn{2}{|c|}{ M odel 5} & \multicolumn{2}{|c|}{ M odel 6} \\
\hline & Prepay & D efault & Prepay & D efault & Prepay & Default & Prepay & D efault \\
\hline $\begin{array}{c}\text { Call Option (fraction } \\
\text { of contract value) }\end{array}$ & $\begin{array}{r}5.810 \\
(89.90)\end{array}$ & $\begin{array}{r}6.324 \\
(16.40)\end{array}$ & $\begin{array}{r}5.779 \\
(88.51)\end{array}$ & $\begin{array}{r}6.749 \\
(17.06)\end{array}$ & $\begin{array}{r}5.921 \\
(83.60)\end{array}$ & $\begin{array}{r}6.550 \\
(17.90)\end{array}$ & $\begin{array}{r}5.891 \\
(81.73)\end{array}$ & $\begin{array}{r}6.877 \\
(18.02)\end{array}$ \\
\hline $\begin{array}{l}\text { Put Option } \\
\text { (probability } \\
\text { of negative } \\
\text { equity) }\end{array}$ & $\begin{array}{l}-4.700 \\
(10.06)\end{array}$ & $\begin{array}{l}15.275 \\
(19.82)\end{array}$ & $\begin{array}{c}-4.312 \\
(8.53)\end{array}$ & $\begin{array}{l}8.670 \\
(9.24)\end{array}$ & $\begin{array}{l}-5.110 \\
(10.61)\end{array}$ & $\begin{array}{l}16.891 \\
(19.05)\end{array}$ & $\begin{array}{r}-4.501 \\
(8.60)\end{array}$ & $\begin{array}{r}9.415 \\
(9.30)\end{array}$ \\
\hline $\begin{array}{l}\text { Squared Term of } \\
\text { Call O ption }\end{array}$ & $\begin{array}{r}4.076 \\
(23.96)\end{array}$ & $\begin{array}{c}-0.269 \\
(0.23)\end{array}$ & $\begin{array}{r}4.133 \\
(23.96)\end{array}$ & $\begin{array}{l}0.194 \\
(0.16)\end{array}$ & $\begin{array}{r}4.135 \\
(23.98)\end{array}$ & $\begin{array}{l}1.057 \\
(0.88)\end{array}$ & $\begin{array}{r}4.242 \\
(23.98)\end{array}$ & $\begin{array}{r}1.032 \\
(0.81)\end{array}$ \\
\hline $\begin{array}{l}\text { Squared Term of } \\
\text { Put Option }\end{array}$ & $\begin{array}{l}4.656 \\
(6.83)\end{array}$ & $\begin{array}{c}-16.333 \\
(14.70)\end{array}$ & $\begin{array}{l}4.268 \\
(5.94)\end{array}$ & $\begin{array}{r}-9.207 \\
(7.44)\end{array}$ & $\begin{array}{l}5.146 \\
(7.40)\end{array}$ & $\begin{array}{c}-17.760 \\
(14.66)\end{array}$ & $\begin{array}{c}4.539 \\
(6.17)\end{array}$ & $\begin{array}{r}-9.882 \\
(7.65)\end{array}$ \\
\hline $0.6<$ LTV $\leq 0.75$ & & & $\begin{array}{l}0.019 \\
(0.60)\end{array}$ & $\begin{array}{l}1.385 \\
(2.15)\end{array}$ & & & $\begin{array}{l}0.018 \\
(0.51)\end{array}$ & $\begin{array}{r}1.351 \\
(2.10)\end{array}$ \\
\hline $0.75<$ LTV $\leq 0.8$ & & & $\begin{array}{l}0.060 \\
(2.06)\end{array}$ & $\begin{array}{r}2.230 \\
(3.73)\end{array}$ & & & $\begin{array}{l}0.053 \\
(1.74)\end{array}$ & $\begin{array}{l}2.194 \\
(3.67)\end{array}$ \\
\hline $0.8<\mathrm{LTV} \leq 0.9$ & & & $\begin{array}{l}0.078 \\
(2.46)\end{array}$ & $\begin{array}{l}3.146 \\
(5.33)\end{array}$ & & & $\begin{array}{l}0.068 \\
(2.05)\end{array}$ & $\begin{array}{r}3.103 \\
(5.25)\end{array}$ \\
\hline LTV $>0.9$ & & & $\begin{array}{r}-0.011 \\
(0.29)\end{array}$ & $\begin{array}{l}3.516 \\
(5.94)\end{array}$ & & & $\begin{array}{r}-0.026 \\
(0.65)\end{array}$ & $\begin{array}{r}3.471 \\
(5.85)\end{array}$ \\
\hline $\begin{array}{l}\text { State U nemploy- } \\
\text { ment R ate } \\
\text { (percent) }\end{array}$ & & & $\begin{array}{r}-0.029 \\
(5.49)\end{array}$ & $\begin{array}{r}0.097 \\
(2.89)\end{array}$ & & & $\begin{array}{c}-0.036 \\
(6.36)\end{array}$ & $\begin{array}{r}0.103 \\
(3.03)\end{array}$ \\
\hline $\begin{array}{l}\text { State D ivorce R ate } \\
\text { (percent) }\end{array}$ & & & $\begin{array}{r}-0.005 \\
(0.43)\end{array}$ & $\begin{array}{l}0.416 \\
(4.55)\end{array}$ & & & $\begin{array}{r}-0.016 \\
(1.20)\end{array}$ & $\begin{array}{r}0.424 \\
(4.57)\end{array}$ \\
\hline $\mathrm{LOCl}$ & $\begin{array}{r}1.972 \\
(37.60)\end{array}$ & $\begin{array}{r}2.577 \\
(7.43)\end{array}$ & $\begin{array}{r}1.696 \\
(12.95)\end{array}$ & $\begin{array}{l}0.058 \\
(1.15)\end{array}$ & $\begin{array}{r}2.803 \\
(11.46)\end{array}$ & $\begin{array}{r}0.036 \\
(0.09)\end{array}$ & $\begin{array}{l}2.619 \\
(7.82)\end{array}$ & $\begin{array}{r}0.015 \\
(0.58)\end{array}$ \\
\hline LOC2 & $\begin{array}{r}0.417 \\
(15.23)\end{array}$ & $\begin{array}{r}2.402 \\
(4.21)\end{array}$ & $\begin{array}{r}0.370 \\
(11.23)\end{array}$ & $\begin{array}{r}0.060 \\
(1.25)\end{array}$ & $\begin{array}{r}0.972 \\
(10.42)\end{array}$ & $\begin{array}{r}3.805 \\
(9.23)\end{array}$ & $\begin{array}{c}0.859 \\
(7.72)\end{array}$ & $\begin{array}{c}0.080 \\
(1.24)\end{array}$ \\
\hline $\mathrm{LOC} 3$ & & & & & $\begin{array}{r}0.135 \\
(3.70)\end{array}$ & $\begin{array}{c}0.221 \\
(1.03)\end{array}$ & $\begin{array}{c}0.116 \\
(3.19)\end{array}$ & $\begin{array}{c}0.009 \\
(0.73)\end{array}$ \\
\hline MASS2 & \multirow{2}{*}{\multicolumn{2}{|c|}{$\begin{array}{c}0.335 \\
(10.28)\end{array}$}} & \multirow{2}{*}{\multicolumn{2}{|c|}{$\begin{array}{c}0.379 \\
(10.26)\end{array}$}} & \multirow{2}{*}{\multicolumn{2}{|c|}{$\begin{array}{l}1.304 \\
(3.69) \\
0.132 \\
(2.85)\end{array}$}} & \multicolumn{2}{|c|}{$\begin{array}{l}1.252 \\
(3.84)\end{array}$} \\
\hline M A SS3 & & & & & & & $\begin{array}{l}0.1 \\
(2.5\end{array}$ & \\
\hline
\end{tabular}

Log Likelihood

$-74,708$

$-74,560$

$-74,673$

$-74,530$

NOTE: $t$ ratios are in parentheses. All models are estimated by $M L$ approach with flexible baseline hazard function Prepayment and default functions are considered as correlated competing risks and they are estimated jointly. A bivariate distribution of unobserved heterogeneous error terms is also estimated simultaneously with the competing risks hazard functions. $L O C 1, L O C 2$, and LOC 3 are the location parameters of the error distribution. MASS1, MASS2, and MASS3 are the mass points associated with $L O C 1, L O C 2$, and $L O C 3$, respectively. MASS1 is normalized to 1.0 during the estimation.

that unobserved heterogeneity is statistically significant in exercising the prepayment option, and the borrowers in the high risk group are about 4.58 times riskier than the borrowers in the low risk group in terms of prepayment risks. The results also show that by adding trigger event variables, M odel 4 has a much better fit than M odel 3, the "ruthless" model. 
Table IV also reports estimates of two models that extend the M odels 3 and 4 by allowing three mass points in the distribution of the unobserved heterogeneities. There are no significant effects on the estimation of the explicitlyspecified explanatory variables. H owever, the three estimated location variables are significantly different from each other, and all the estimated mass points are significant in the prepayment function. The log likelihood values also suggest that Model 5 and Model 6 provide better fit to the data than Models 3 and 4 , respectively.

The estimates from both M odels 5 and 6 suggest that over forty percent of the borrowers are in the group most likely to exercise the mortgage prepayment option (e.g., $1 /[1+1.252+0.119])$. A bout 5 percent of the borrowers are much slower in exercising the mortgage prepayment option (e.g., $0.119 /[1+1.252+$ $0.119])$. The behavior of the remaining half of the borrowers is somewhere in between these two extreme groups. The estimates also suggest that given the same market and economic environment (i.e., given the market interest rate, pattern of house price appreciation/depreciation rate, unemployment, and divorce rates, etc.), the high risk group is about three times riskier than the intermediate group, and about twenty times riskier than the low risk group in terms of prepayment. H owever, the results also show that heterogeneity is less important among borrowers in terms of exercising the default option. ${ }^{16}$

Figure 2 graphs the average conditional prepayment and default rates by mortgage age estimated by M odel 6 for the three groups. Panel $A$ indicates that conditional prepayment rates increase from about 2 percent, on average, after 5 years, to about 6 percent after 8 years. However, the average masks quite different behavior among the three groups. For the middle group, the estimated prepayment rate increases from about 1.5 percent to 4 percent, while for the third (low risk) group the conditional prepayment rate changes only a little. A mong the first (the high risk) group, however, conditional prepayment rates increase from about 3 percent after 5 years to about 11 percent after 8 years.

Panel $B$ reports the average conditional default rates estimated for the three groups. The panel confirms that inverted $U$ shaped function implied by theory (e.g., Quigley and Van Order (1995)), but again there are large behavioral differences among groups. At the peak, after about 6 years, conditional default rates are less than 0.02 percent for those in group 1 and about 5 times as large for those in group 3. U nobserved heterogeneity matters a lot in the behavior of mortgage holders.

\footnotetext{
${ }^{16}$ We have sought to extend the models reported in Table IV to estimate additional mass points in the distribution of unobserved heterogeneity. When four mass points are estimated, the value of the log likelihood function is unchanged (to five significant digits), and several of the estimated location and mass points are insignificant. The fraction of borrowers classified into the high risk extreme (41 percent) is about the same; the fraction classified into the low risk extreme is about zero (but the coefficient on the mass point is insignificant). When five or six mass points are estimated, the coefficients are insignificant. In all these estimations, however, the coefficients of the option variables and the other parameters are virtually unchanged.
} 


\section{A. Estimated Conditional Prepayment Rates}

For Three Risk Groups (Model 6)

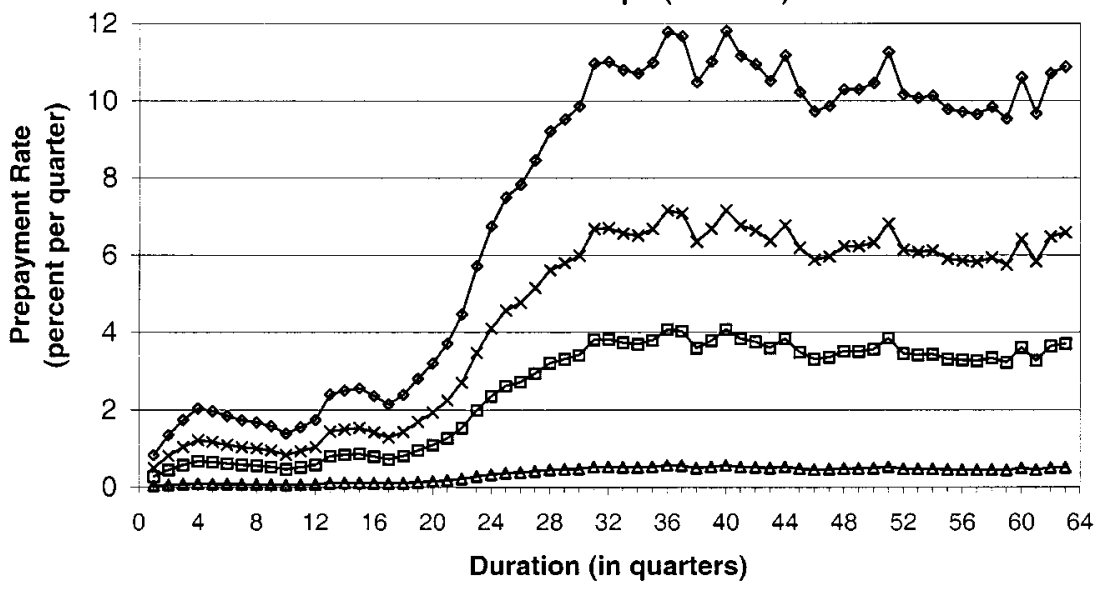

$\rightarrow$ Group $1 \rightarrow$ Group $2 \rightarrow$ Group $3 \rightarrow$ Average

B. Estimated Conditional Default Rates For Three Risk Groups (Model 6)

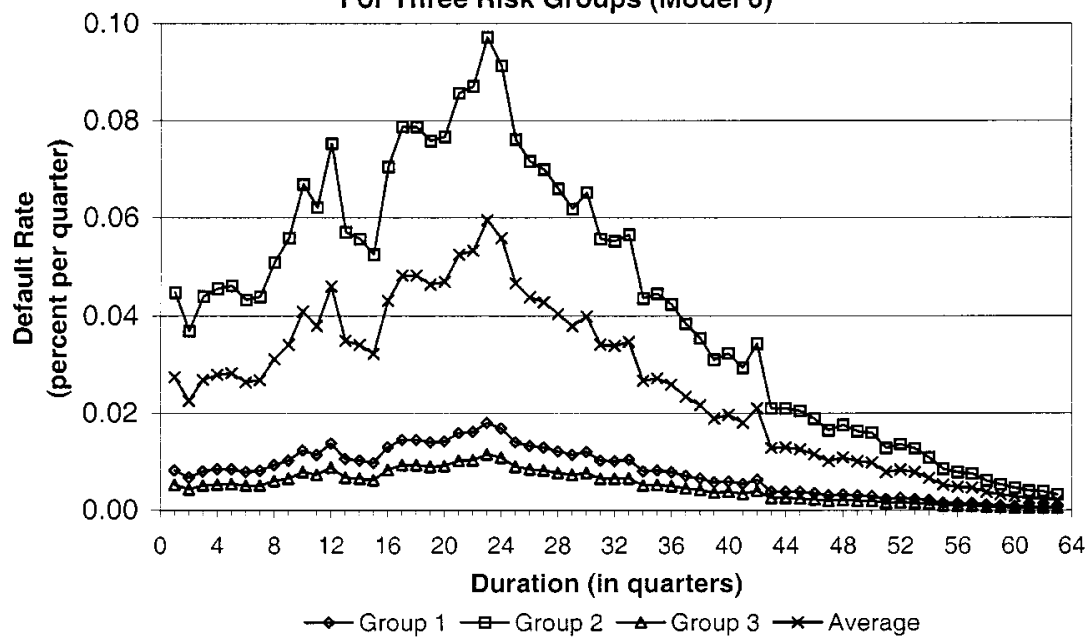

FIGURE 2

Table $\mathrm{V}$ reports the results of estimating the mortgage prepayment risk and default risk functions independently using three and two mass points respectively (the best fitting models). The qualitative pattern of the estimated coefficients is similar. However, it is quite clear that, for this sample at least, ignoring the interdependence between prepayment risk and default risk has a 
substantial effect upon the accuracy of the estimation, especially for the default function. ${ }^{17}$

Figure 3 summarizes the predictions of the various specifications of the competing risks models, indicating the conditional prepayment and default rates predicted by M odel 2 (interdependent risks, no heterogeneity), M odel 5 (frictionless model, interdependent risks, heterogeneity), Model 6 (interdependent risks, heterogeneity), and M odel 8 (independent risks, heterogeneity). A gain the mean value of the simulated conditional prepayment and default rates are presented here. The predictions of the models are similar, but they are certainly not identical. The specification preferred on statistical grounds, M odel 6 , does yield substantially different predictions.

Figure 4 reports the cumulative prepayment and default rates estimated by M odel 6 for three origination year cohorts: 1978:IV, 1980:IV, and 1982:IV. The figure also reports the raw unadjusted Kaplan-M eier cumulative rates. The economic model tracks the raw data well, on average, but there is more volatility in the unadjusted data than in the predictions of the model. In particular, the covariates do not capture the rapid increase in termination by prepayment during 1985-1986.

\subsection{Regional Variation}

In this section we present additional estimates of the interdependent competing risks model with heterogeneity for two regions, California and Texas. The California economy was strong and growing throughout most of the sample period, while the Texas economy was a victim of the oil crisis and a prolonged depression. For California, we draw a simple random sample of ten percent $(22,374$ loans) out of the population of $(222,656)$ loans. For Texas, we analyze the full sample of $(29,310)$ loans.

Table VI reports the means and standard deviations of the explanatory variables in these two states at mortgage origination and at termination. When all loans are compared at origination with the national sample (Table I), the average value of the call option is very similar, and the initial LTV 's are not very different. However, at origination the probability of negative equity is only a third as large for California loans as for the US as a whole, while for Texas the probability of negative equity is more than twice as large as elsewhere. The qualitative pattern of the averages for California and Texas, however, are similar to those reported in Table I for the US as a whole.

D espite these patterns, there are substantial quantitative differences between the two states. The average value of the call option is larger (i.e., less negative)

\footnotetext{
${ }^{17} \mathrm{M}$ odel 7 and M odel 8 are estimated based on the same sample of $(22,294)$ loans that are used for estimating $M$ odel 5 and $M$ odel 6 . Table $V$ reports that for $M$ odel 8 , the log likelihood values are $-80,935$ and $-417,644$ for prepayment and default functions, respectively (compared to $-74,530$ in Model 6). The large negative value of the log likelihood function in the estimation of the independent default hazard model arises mainly because only $1.6 \%$ of the sample are defaulted loans.
} 
TABLE V

Maximum Likelihood Estimates for Independent Risks of Mortgage Prepayment and Default With Unobserved Heterogeneity

\begin{tabular}{|c|c|c|c|c|}
\hline & \multicolumn{2}{|c|}{ M odel 7} & \multicolumn{2}{|c|}{ M odel 8} \\
\hline & Prepayment & D efault & Prepayment & Default \\
\hline $\begin{array}{l}\text { Call O ption (fraction of } \\
\text { contract value) }\end{array}$ & $\begin{array}{r}6.002 \\
(83.51)\end{array}$ & $\begin{array}{r}8.348 \\
(21.07)\end{array}$ & $\begin{array}{r}5.976 \\
(82.24)\end{array}$ & $\begin{array}{r}8.520 \\
(21.34)\end{array}$ \\
\hline $\begin{array}{l}\text { Put O ption (probability } \\
\text { of negative equity) }\end{array}$ & $\begin{array}{c}-3.989 \\
(8.37)\end{array}$ & $\begin{array}{l}15.743 \\
(17.96)\end{array}$ & $\begin{array}{c}-3.622 \\
(7.03)\end{array}$ & $\begin{array}{r}8.189 \\
(7.83)\end{array}$ \\
\hline $\begin{array}{l}\text { Squared Term of Call } \\
\text { Option }\end{array}$ & $\begin{array}{r}4.287 \\
(24.53)\end{array}$ & $\begin{array}{l}4.242 \\
(3.20)\end{array}$ & $\begin{array}{r}4.383 \\
(24.62)\end{array}$ & $\begin{array}{r}3.374 \\
(2.57)\end{array}$ \\
\hline $\begin{array}{l}\text { Squared Term of Put } \\
\text { Option }\end{array}$ & $\begin{array}{l}4.260 \\
(6.12)\end{array}$ & $\begin{array}{c}-16.803 \\
(12.78)\end{array}$ & $\begin{array}{r}3.911 \\
(5.33)\end{array}$ & $\begin{array}{r}-9.042 \\
(6.23)\end{array}$ \\
\hline $0.6<\mathrm{LTV} \leq 0.75$ & & & $\begin{array}{l}0.020 \\
(0.60)\end{array}$ & $\begin{array}{r}1.327 \\
(2.07)\end{array}$ \\
\hline $0.75<$ LTV $\leq 0.8$ & & & $\begin{array}{l}0.059 \\
(1.95)\end{array}$ & $\begin{array}{r}2.372 \\
(3.98)\end{array}$ \\
\hline $0.8<$ LTV $\leq 0.9$ & & & $\begin{array}{l}0.083 \\
(2.52)\end{array}$ & $\begin{array}{r}3.370 \\
(5.74)\end{array}$ \\
\hline LTV $>0.9$ & & & $\begin{array}{l}0.009 \\
(0.22)\end{array}$ & $\begin{array}{r}3.333 \\
(5.66)\end{array}$ \\
\hline $\begin{array}{l}\text { State } U \text { nemployment } \\
\text { R ate (percent) }\end{array}$ & & & $\begin{array}{c}-0.033 \\
(5.96)\end{array}$ & $\begin{array}{r}0.166 \\
(5.04)\end{array}$ \\
\hline $\begin{array}{l}\text { State D ivorce R ate } \\
\text { (percent) }\end{array}$ & & & $\begin{array}{c}-0.006 \\
(0.46)\end{array}$ & $\begin{array}{r}0.390 \\
(4.24)\end{array}$ \\
\hline LOC1 & $\begin{array}{r}2.630 \\
(11.92)\end{array}$ & $\begin{array}{l}10.857 \\
(7.05)\end{array}$ & $\begin{array}{l}2.308 \\
(8.16)\end{array}$ & $\begin{array}{r}0.144 \\
(1.23)\end{array}$ \\
\hline LOC2 & $\begin{array}{l}0.901 \\
(8.28)\end{array}$ & $\begin{array}{l}0.506 \\
(1.97)\end{array}$ & $\begin{array}{c}0.759 \\
(7.13)\end{array}$ & $\begin{array}{r}0.011 \\
(0.99)\end{array}$ \\
\hline LOC3 & $\begin{array}{l}0.109 \\
(2.78)\end{array}$ & & $\begin{array}{l}0.095 \\
(2.73)\end{array}$ & \\
\hline MASS2 & $\begin{array}{l}1.017 \\
(3.52)\end{array}$ & $\begin{array}{l}0.628 \\
(3.42)\end{array}$ & $\begin{array}{l}1.033 \\
(3.87)\end{array}$ & $\begin{array}{r}0.344 \\
(2.31)\end{array}$ \\
\hline M ASS3 & $\begin{array}{l}0.100 \\
(2.37)\end{array}$ & & $\begin{array}{c}0.099 \\
(2.39)\end{array}$ & \\
\hline Log Likelihood & $-80,968$ & $-417,754$ & $-80,935$ & $-417,644$ \\
\hline
\end{tabular}

in California at origination and at termination for mortgages of all types. Conversely, the average probability of negative equity is larger in Texas at origination for mortgages of all types. In part, this reflects the higher average LTV in Texas.

In both states, the average unemployment rate at termination by default is higher than at termination by prepayment, but in Texas the average unemployment rate at termination is almost forty percent higher than at origination. 


\section{A. Simulated Conditional Prepayment Rates}

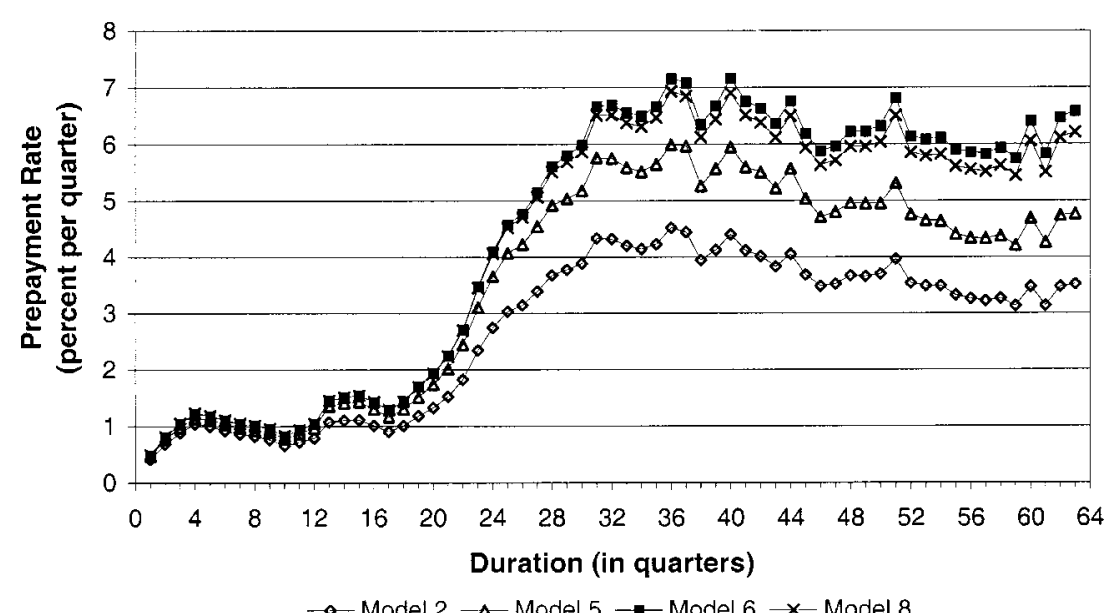

B. Simulated Conditional Default Rates

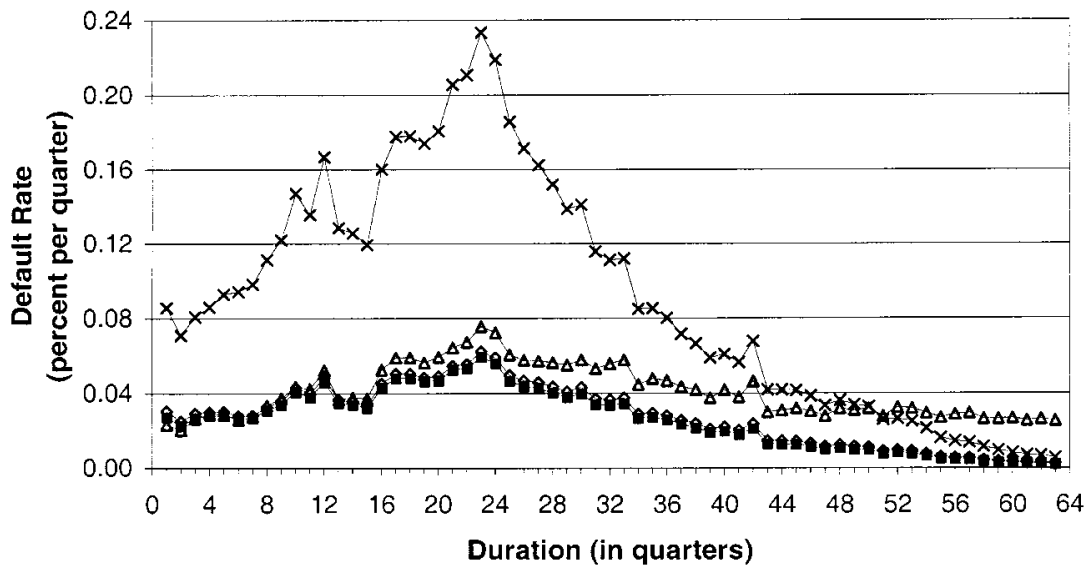

- Model $2-\Delta-$ Model $5 \rightarrow$ Model $6 \rightarrow$ Model 8

FIGURE 3

D ifferences between the two states in the averages of the variable measuring the value of the put option are particularly striking. In California, for those mortgages terminating by default, the probability of negative equity at origination is about 2 percent; the probability of negative equity at termination is about 2.5 percent. In Texas, however, for defaulted mortgages, the probability of negative equity is more than 5 percent at origination (raising real questions about the oversight provided by lending organizations, mostly savings and loan 
A. Estimated Cumulative Prepayment Rates by Origination Year Cohort (Model 6)

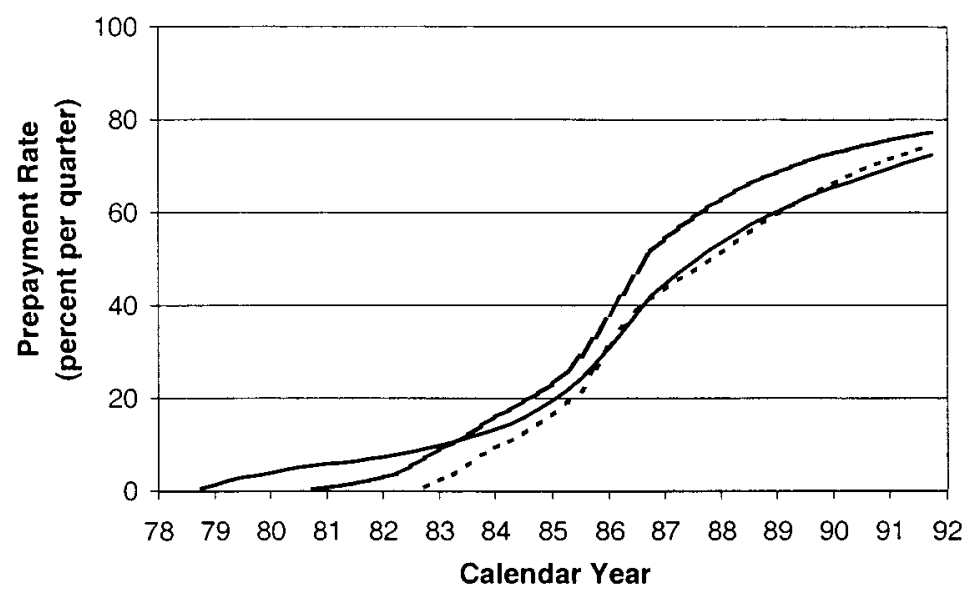

1978:IV Cohort - - - 1980:IV Cohort - - - - 1982:IV Cohort

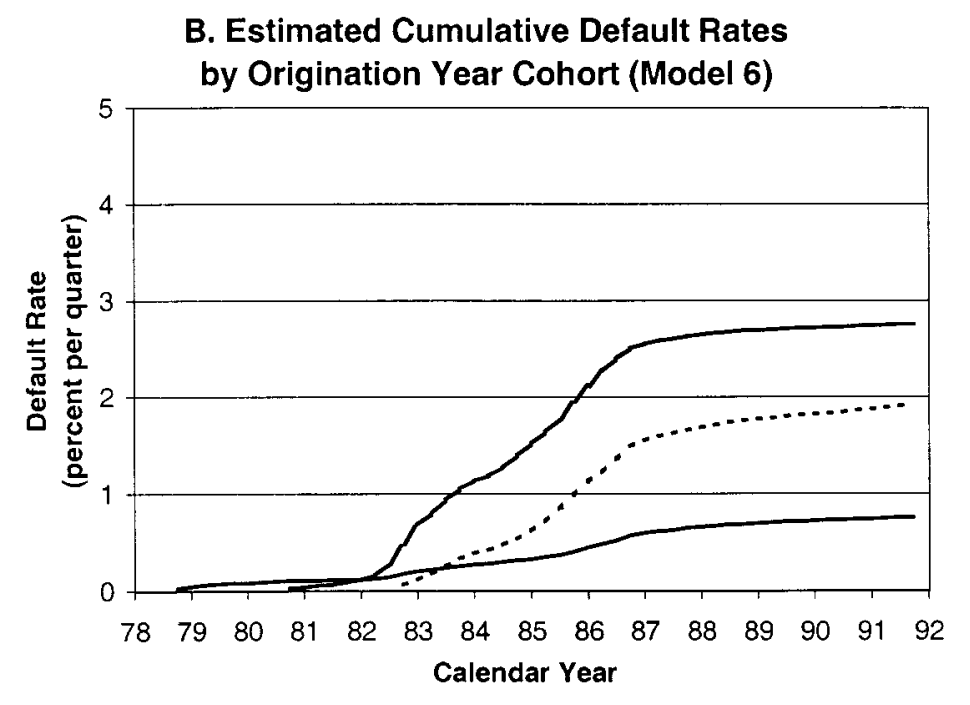

1978:IV Cohort - - - 1980:IV Cohort - . - 1982:IV Cohort

FIGURE 4 
C. Kaplan-Meier Cumulative Prepayment Rates by Origination Year Cohort

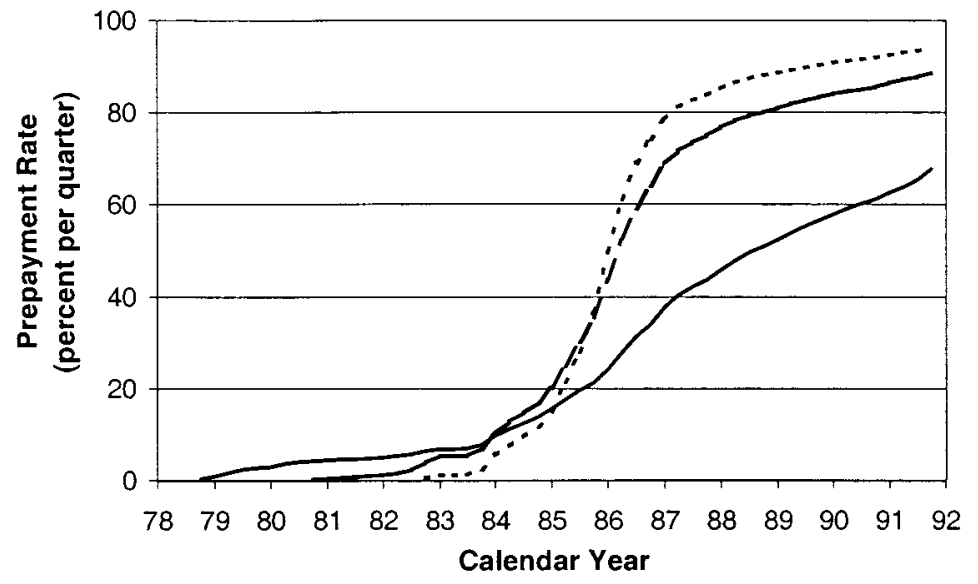

- 1978:IV Cohort - - - 1980:IV Cohort - - - 1982:IV Cohort

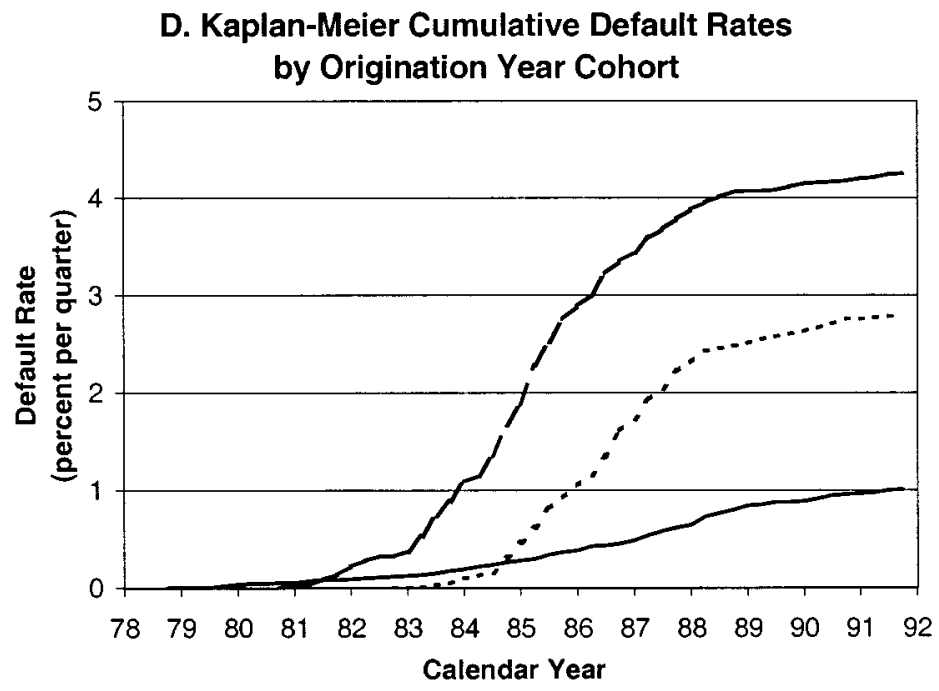

1978:IV Cohort - - - 1980:IV Cohort - - - - 1982:IV Cohort

FIgURE 4 (Continued) 
TABLE VI

Descriptive Statistics on California and Texas Mortgage Loans Mean Valuesat Origination and Termination

\begin{tabular}{|c|c|c|c|c|c|c|}
\hline \multirow[b]{2}{*}{ Variable } & \multicolumn{4}{|c|}{ At Origination } & \multicolumn{2}{|c|}{ At Termination } \\
\hline & All Loans & Prepaid & Defaulted & Other ${ }^{a}$ & Prepaid & D efaulted \\
\hline \multicolumn{7}{|l|}{ A. California } \\
\hline $\begin{array}{l}\text { Call O ption (fraction of } \\
\text { contract value) }\end{array}$ & $\begin{array}{r}-0.0505 \\
(0.0055)\end{array}$ & $\begin{array}{r}-0.0526 \\
(0.0060)\end{array}$ & $\begin{array}{r}-0.0628 \\
(0.0095)\end{array}$ & $\begin{array}{r}-0.0414 \\
(0.0033)\end{array}$ & $\begin{array}{r}-0.0078 \\
(0.0293)\end{array}$ & $\begin{array}{r}0.1000 \\
(0.0214)\end{array}$ \\
\hline $\begin{array}{c}\text { Put O ption (probability } \\
\text { of negative equity) }\end{array}$ & $\begin{array}{l}0.0027 \\
(0.0002)\end{array}$ & $\begin{array}{c}0.0027 \\
(0.0002)\end{array}$ & $\begin{array}{c}0.0194 \\
(0.0013)\end{array}$ & $\begin{array}{c}0.0013 \\
(0.0001)\end{array}$ & $\begin{array}{l}0.0026 \\
(0.0001)\end{array}$ & $\begin{array}{c}0.0246 \\
(0.0012)\end{array}$ \\
\hline State U nemployment & 7.3038 & 7.3018 & 7.4231 & 7.3015 & 6.6792 & 7.0468 \\
\hline $\mathrm{R}$ ate (percent) & (1.4484) & (1.5275) & (1.6332) & (1.1215) & (1.7284) & (1.3618) \\
\hline $\begin{array}{l}\text { State Divorce R ate } \\
\text { (percent) }\end{array}$ & $\begin{array}{l}5.7825 \\
(0.0534)\end{array}$ & $\begin{array}{l}5.7652 \\
(0.0552)\end{array}$ & $\begin{array}{l}5.5526 \\
(0.0310)\end{array}$ & $\begin{array}{l}5.8712 \\
(0.0222)\end{array}$ & $\begin{array}{l}5.0259 \\
(0.2258)\end{array}$ & $\begin{array}{r}5.1504 \\
(0.0785)\end{array}$ \\
\hline $\begin{array}{l}\text { Initial Loan-To-V alue } \\
\text { Ratio (LTV) }\end{array}$ & $\begin{array}{c}0.7581 \\
(0.0213)\end{array}$ & $\begin{array}{c}0.7575 \\
(0.0217)\end{array}$ & $\begin{array}{c}0.8655 \\
(0.0056)\end{array}$ & $\begin{array}{c}0.7514 \\
(0.0203)\end{array}$ & - & - \\
\hline No. of Observations & 22,374 & 17,598 & 359 & 4,417 & 17,598 & 359 \\
\hline \multicolumn{7}{|l|}{ B. Texas } \\
\hline $\begin{array}{l}\text { Call O ption (fraction of } \\
\text { contract value) }\end{array}$ & $\begin{array}{r}-0.0616 \\
(0.0095)\end{array}$ & $\begin{array}{r}-0.0631 \\
(0.0098)\end{array}$ & $\begin{array}{r}-0.0889 \\
(0.0185)\end{array}$ & $\begin{array}{r}-0.0552 \\
(0.0074)\end{array}$ & $\begin{array}{r}-0.0680 \\
(0.0403)\end{array}$ & $\begin{array}{r}0.0364 \\
(0.0178)\end{array}$ \\
\hline $\begin{array}{l}\text { Put O ption (probability } \\
\text { of negative equity) }\end{array}$ & $\begin{array}{c}0.0159 \\
(0.0010)\end{array}$ & $\begin{array}{c}0.0119 \\
(0.0008)\end{array}$ & $\begin{array}{c}0.0531 \\
(0.0028)\end{array}$ & $\begin{array}{c}0.0151 \\
(0.0009)\end{array}$ & $\begin{array}{l}0.0507 \\
(0.0212)\end{array}$ & $\begin{array}{r}0.2690 \\
(0.0879)\end{array}$ \\
\hline State U nemployment & 5.1320 & 5.2463 & 5.2709 & 4.9635 & 7.2736 & 7.3154 \\
\hline $\mathrm{R}$ ate (percent) & $(0.7868)$ & (0.9558) & (1.4325) & $(0.4193)$ & (1.6342) & $(1.0645)$ \\
\hline $\begin{array}{l}\text { State Divorce R ate } \\
\text { (percent) }\end{array}$ & $\begin{array}{c}6.4923 \\
(0.0384)\end{array}$ & $\begin{array}{c}6.5083 \\
(0.0584)\end{array}$ & $\begin{array}{c}6.5674 \\
(0.0543)\end{array}$ & $\begin{array}{c}6.4556 \\
(0.0519)\end{array}$ & $\begin{array}{l}5.9555 \\
(0.0923)\end{array}$ & $\begin{array}{r}5.7162 \\
(0.0583)\end{array}$ \\
\hline $\begin{array}{l}\text { Initial Loan-To-V alue } \\
\text { Ratio (LTV) }\end{array}$ & $\begin{array}{l}0.8007 \\
(0.0267)\end{array}$ & $\begin{array}{c}0.7828 \\
(0.0274)\end{array}$ & $\begin{array}{c}0.9086 \\
(0.0084)\end{array}$ & $\begin{array}{c}0.8063 \\
(0.0265)\end{array}$ & - & - \\
\hline No. of Observations & 29,310 & 15,364 & 1,919 & 12,027 & 15,364 & 1,919 \\
\hline
\end{tabular}

NOTE: Standard deviations are in parentheses.

a "Other" includes matured mortgages as well as those outstanding at the end of the observation period.

institutions, during the period). At termination, the probability of negative equity is almost 27 percent.

Table VII reports the coefficient estimates of the behavioral model for California and Texas. The model is estimated to include a bivariate distribution of unobserved heterogeneous error terms. ${ }^{18} \mathrm{~F}$ or convenience the relevant model from Table IV for the U S as a whole is reproduced.

With only three exceptions involving insignificant coefficients, the pattern of the estimated coefficients is the same for the two states, but the magnitudes of the estimates vary. Each of the key financial variables exerts a substantial direct

\footnotetext{
${ }^{18} \mathrm{~A}$ gain, attempts to estimate three or more mass points failed. For California, the maximum likelihood estimation with three mass points yields imprecise estimates, and the log likelihood ratio remains the same as in Table VII. For Texas, the estimation with 3 mass points does not converge at all.
} 
TABLE VII

Comparison of Prepayment and Default Rates among US, California, and Texas loans ${ }^{\text {a }}$

\begin{tabular}{|c|c|c|c|c|c|c|}
\hline & \multicolumn{2}{|c|}{ US } & \multicolumn{2}{|c|}{ Califomia } & \multicolumn{2}{|c|}{ Texas } \\
\hline & Prepayment & D efault & Prepayment & Default & Prepayment & Default \\
\hline $\begin{array}{l}\text { Call O ption (fraction of } \\
\text { contract value) }\end{array}$ & $\begin{array}{r}5.779 \\
(88.51)\end{array}$ & $\begin{array}{r}6.750 \\
(17.06)\end{array}$ & $\begin{array}{r}5.769 \\
(97.84)\end{array}$ & $\begin{array}{r}9.081 \\
(21.39)\end{array}$ & $\begin{array}{r}5.269 \\
(68.22)\end{array}$ & $\begin{array}{r}7.503 \\
(27.92)\end{array}$ \\
\hline $\begin{array}{l}\text { Put O ption (probability } \\
\text { of negative equity) }\end{array}$ & $\begin{array}{r}-4.312 \\
(8.53)\end{array}$ & $\begin{array}{l}8.669 \\
(9.24)\end{array}$ & $\begin{array}{r}-11.837 \\
(8.58)\end{array}$ & $\begin{array}{l}20.872 \\
(4.73)\end{array}$ & $\begin{array}{l}-1.917 \\
(10.80)\end{array}$ & $\begin{array}{r}4.892 \\
(15.24)\end{array}$ \\
\hline $\begin{array}{l}\text { Squared Term of Call } \\
\text { Option }\end{array}$ & $\begin{array}{r}4.133 \\
(23.96)\end{array}$ & $\begin{array}{l}0.193 \\
(0.15)\end{array}$ & $\begin{array}{r}3.568 \\
(19.11)\end{array}$ & $\begin{array}{r}1.869 \\
(1.34)\end{array}$ & $\begin{array}{r}3.421 \\
(20.61)\end{array}$ & $\begin{array}{r}1.430 \\
(1.57)\end{array}$ \\
\hline $\begin{array}{l}\text { Squared Term of Put } \\
\text { Option }\end{array}$ & $\begin{array}{c}4.268 \\
(5.94)\end{array}$ & $\begin{array}{r}-9.206 \\
(7.44)\end{array}$ & $\begin{array}{l}45.372 \\
(4.74)\end{array}$ & $\begin{array}{r}-92.270 \\
(3.33)\end{array}$ & $\begin{array}{r}1.791 \\
(7.68)\end{array}$ & $\begin{array}{r}-2.676 \\
(6.78)\end{array}$ \\
\hline $0.6<\mathrm{LTV} \leq 0.75$ & $\begin{array}{l}0.019 \\
(0.60)\end{array}$ & $\begin{array}{l}1.385 \\
(2.15)\end{array}$ & $\begin{array}{r}0.057 \\
(2.01)\end{array}$ & $\begin{array}{r}2.802 \\
(3.84)\end{array}$ & $\begin{array}{r}0.046 \\
(1.39)\end{array}$ & $\begin{array}{l}1.136 \\
(5.45)\end{array}$ \\
\hline $0.75<\mathrm{LTV} \leq 0.8$ & $\begin{array}{l}0.060 \\
(2.06)\end{array}$ & $\begin{array}{r}2.230 \\
(3.73)\end{array}$ & $\begin{array}{c}-0.006 \\
(0.24)\end{array}$ & $\begin{array}{r}2.955 \\
(4.12)\end{array}$ & $\begin{array}{c}-0.005 \\
(0.17)\end{array}$ & $\begin{array}{l}1.493 \\
(8.26)\end{array}$ \\
\hline $0.8<\mathrm{LTV} \leq 0.9$ & $\begin{array}{r}0.078 \\
(2.46)\end{array}$ & $\begin{array}{r}3.146 \\
(5.33)\end{array}$ & $\begin{array}{l}0.074 \\
(2.65)\end{array}$ & $\begin{array}{r}3.747 \\
(5.23)\end{array}$ & $\begin{array}{r}-0.043 \\
(1.37)\end{array}$ & $\begin{array}{r}2.045 \\
(11.91)\end{array}$ \\
\hline $\mathrm{LTV}>0.9$ & $\begin{array}{r}-0.011 \\
(0.29)\end{array}$ & $\begin{array}{r}3.517 \\
(5.94)\end{array}$ & $\begin{array}{l}0.023 \\
(0.45)\end{array}$ & $\begin{array}{r}4.193 \\
(5.77)\end{array}$ & $\begin{array}{l}-0.322 \\
(10.43)\end{array}$ & $\begin{array}{r}2.759 \\
(16.59)\end{array}$ \\
\hline $\begin{array}{l}\text { State } U \text { nemployment } \\
\text { R ate (percent) }\end{array}$ & $\begin{array}{c}-0.029 \\
(5.49)\end{array}$ & $\begin{array}{r}0.097 \\
(2.89)\end{array}$ & $\begin{array}{r}-0.017 \\
(2.73)\end{array}$ & $\begin{array}{c}-0.151 \\
(2.47)\end{array}$ & $\begin{array}{r}0.011 \\
(1.48)\end{array}$ & $\begin{array}{r}-0.115 \\
(4.47)\end{array}$ \\
\hline $\begin{array}{l}\text { State D ivorce R ate } \\
\text { (percent) }\end{array}$ & $\begin{array}{r}-0.005 \\
(0.43)\end{array}$ & $\begin{array}{l}0.416 \\
(4.55)\end{array}$ & $\begin{array}{r}0.527 \\
(23.34)\end{array}$ & $\begin{array}{r}0.467 \\
(1.89)\end{array}$ & $\begin{array}{r}0.368 \\
(11.05)\end{array}$ & $\begin{array}{r}0.265 \\
(2.52)\end{array}$ \\
\hline LOC1 & $\begin{array}{l}1.696 \\
(12.95)\end{array}$ & $\begin{array}{l}0.058 \\
(1.15)\end{array}$ & $\begin{array}{l}0.106 \\
(8.00)\end{array}$ & $\begin{array}{r}0.035 \\
(0.70)\end{array}$ & $\begin{array}{c}0.104 \\
(4.38)\end{array}$ & $\begin{array}{r}0.717 \\
(1.56)\end{array}$ \\
\hline LOC2 & $\begin{array}{r}0.370 \\
(11.23)\end{array}$ & $\begin{array}{r}0.060 \\
(1.25)\end{array}$ & $\begin{array}{r}0.020 \\
(3.54)\end{array}$ & $\begin{array}{r}0.001 \\
(0.30)\end{array}$ & $\begin{array}{r}0.021 \\
(4.04)\end{array}$ & $\begin{array}{r}0.036 \\
(1.46)\end{array}$ \\
\hline MASS2 & $\begin{array}{r}0.3 \\
(10\end{array}$ & & $\begin{array}{l}0.0 \\
(3 .\end{array}$ & & & \\
\hline Log Likelihood & -74 & & -7 & & $-\varepsilon$ & \\
\hline
\end{tabular}

NOTE: $\mathrm{t}$ ratios are in parentheses. All models are estimated by $M L$ approach with flexible baseline hazard function. Prepayment and default functions are considered as correlated competing risks and they are estimated jointly. A bivariate distribution of unobserved heterogeneous error terms is also estimated simultaneously with the competing risks hazard functions. LOC1 and LOC2 are the location parameters of the error distribution. M ASS1 and M A SS2 are the mass points associated with $L O C 1$ and $L O C 2$, respectively. MASS1 is normalized to 1.0 during the estimation.

${ }^{a}$ The U S sample is based on a five percent random sample of 22,294 loans. The California sample is based on a ten percent random sample of 22,374 loans. The Texas sample is based on a hundred percent sample of 29,310 loans.

effect upon the exercise of both options. For Texas loans, in contrast to California loans or US loans in general, there appears to be substantial heterogeneity in default behavior (however, the t statistics associated with LOC1 and LOC2 are barely significant). Individuals in the first group are almost 20 times as likely to default, ceteris paribus, than those classified in the second group. This difference is not precisely estimated, but it suggests substantially different behavior among Texas borrowers.

Figure 5 presents the prepayment and default rates for California and Texas estimated using the separate models reported in Table V II. Panel A reports the prepayment rates, illustrating the higher conditional rates in California after 


\section{A. Estimated Conditional Prepayment Rates in California and Texas}

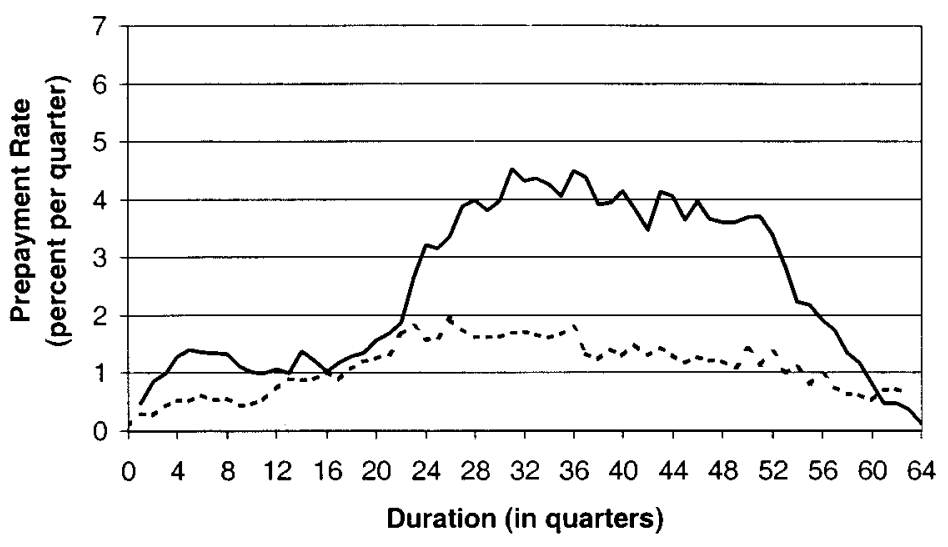

California -...- - Texas

B. Estimated Conditional Default Rates in California and Texas

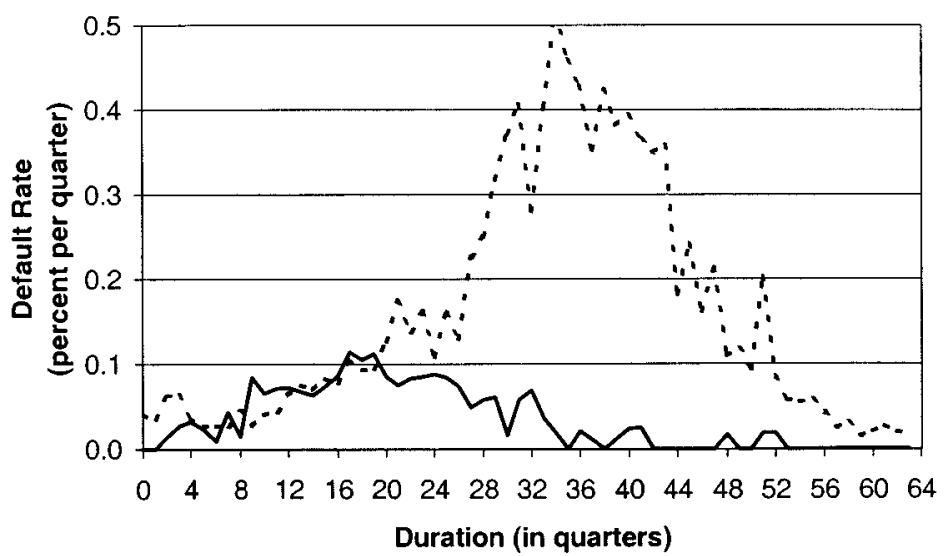

—California .... - Texas

FIGURE 5 
C. Simulated Conditional Prepayment Rates in California and Texas using Model 4 for US

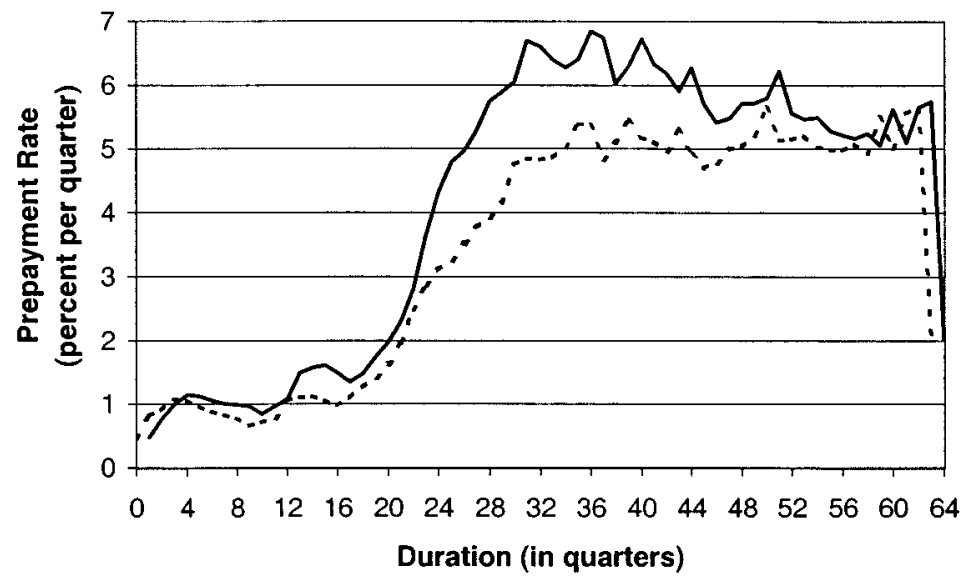

- California -...- Texas

\section{Simulated Conditional Default Rates}

in California and Texas using Model 4 for US

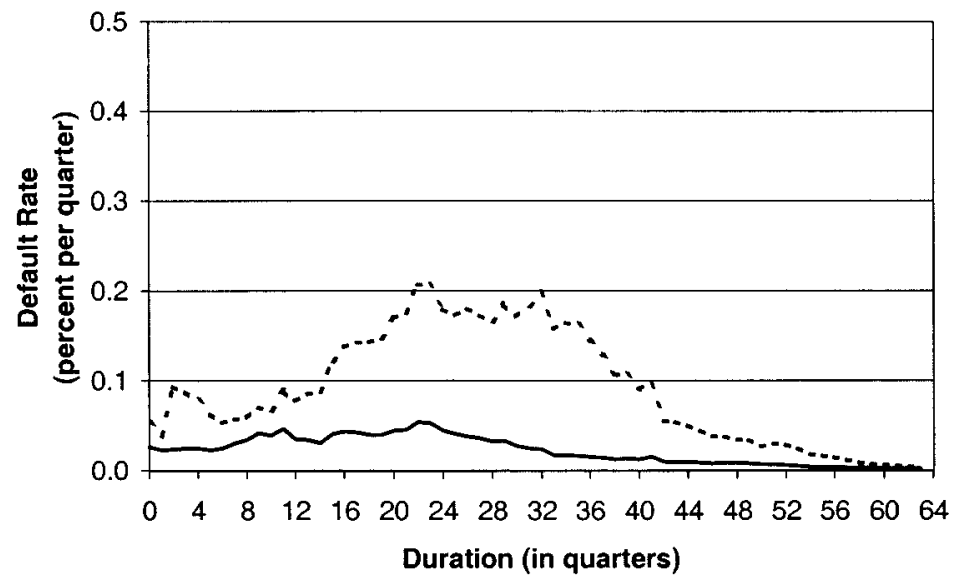

- California ..... Texas

Figure 5 (Continued) 
about six years, while Panel B illustrates the much higher conditional default rates predicted in Texas after about six years. Panels $C$ and $D$ report the simulated average prepayment and default rates using the coefficients from the national model (columns 1 and 2 of Table VII) and the realizations in the data for California and Texas. The projected differences for the two states are qualitatively similar, but the national model understates the divergence in the behavior of mortgage holders in the two states. R egional differences matter a lot, even beyond the differences in the course of housing and labor markets.

\section{CONCLUSION}

This paper has presented a unified model of the competing risks of mortgage termination by prepayment and default. The model considers these two hazards as dependent competing risks and estimates them jointly. The model also accounts for the unobserved heterogeneity among borrowers, and estimates the unobserved heterogeneity simultaneously with the parameters and baseline hazards associated with prepayment and default functions.

The substantive results of the analysis provide support for the contingent claims model, which predicts the exercise of financial options. The financial value of the call option is strongly associated with exercise of the prepayment option, and the probability that the put option is in the money is strongly associated with exercise of the default option. The results also provide strong support for the interdependence of the decisions to prepay and to default on mortgage obligations.

The results also show that there exists significant heterogeneity among mortgage borrowers, particularly regarding prepayment. The results indicate that ignoring heterogeneity among mortgage borrowers leads to serious errors in estimating the prepayment risk. M oreover, forecasts that ignore the interdependence between default and prepayment risks and that estimate these two risks separately lead to serious errors in estimating the default risk.

The results also point to differences in prepayment and default behavior across regions, arising from variations in institutions or behavioral responses as well as variations in market conditions.

Further, the results suggest that, holding other things constant, those who have chosen high initial LTV loans are more likely to exercise options in the mortgage market-prepayment as well as default. It appears that the initial LTV ratio, known at the time mortgages are issued, may well reflect investor preferences for risk in the market for mortgages on owner-occupied housing. Finally, unemployment and divorce rates have significant effects on default. Taken together, all these results suggest that the simple option model is not enough. 
University of Southern California, Los Angeles, CA 90089-0626, U.S.A.; ydeng@usc.edu,

University of California, Berkeley, CA 94720-3880, U.S.A.; quigley@ econ.berke ley.edu,

and

Freddie Mac, 8200 Jones Branch Drive, McLean, VA 22102, U.S.A.; order_van@ freddiemac.com.

Manuscript received May, 1995; final revision received February, 1999.

ApPendix A: Specifications of "Call_Option" and "Put_Option" Variables

The variables measuring the value of the put and call options are defined by the initial terms of the mortgage and current market conditions. For fixed-rate level-payment mortgage $i$ with an original loan amount of $\mathrm{O}_{i}$, a mortgage note rate of $\mathrm{r}_{\mathrm{i}}$, and a monthly payment of $\mathrm{P}_{\mathrm{i}}$, in principal and interest, the mortgage term in quarters, $\mathrm{TM}_{\mathrm{i}}$, is

$$
\mathrm{TM}_{\mathrm{i}}=\frac{\log \left(\frac{\mathrm{P}_{\mathrm{i}}-\mathrm{O}_{\mathrm{i}} \times\left(\mathrm{r}_{\mathrm{i}} / 1200\right)}{\mathrm{P}_{\mathrm{i}}}\right)}{\log \left(\frac{1}{1+\mathrm{r}_{\mathrm{i}} / 1200}\right) \times 3} .
$$

At each quarter $k$ after origination at time $\tau_{i}$, the local market interest rate is $m_{j, \tau_{i}+k}$, where $j$ indexes the local region. The "Call_Option" variable is defined as the difference in the present values of the payment stream at the mortgage note rate and the current interest rate:

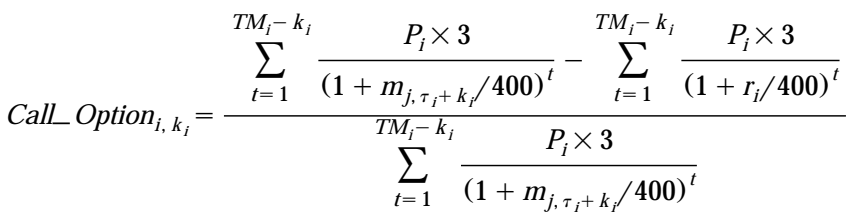

$$
\begin{aligned}
& =\frac{V_{i, m j, \tau_{i}+k_{i}}-V_{i, r_{i}}^{*}}{V_{i, m j, \tau_{i}+k_{i}}} .
\end{aligned}
$$

As shown in A ppendix $B$, the market value $M_{i}$ of property $i$, purchased at a cost of $C_{i}$ at time $\tau_{i}$ and evaluated $k_{i}$ quarters thereafter is

$$
M_{i, k_{i}}=C_{i}\left(\frac{I_{j, \tau_{i} k+i_{i}}}{I_{j, \tau_{i}}}\right)
$$

where the term in parentheses follows a log normal distribution.

The ratio of equity to market value, $E$, of the property $i$ is

$$
E_{i, k_{i}}=\frac{M_{i, k_{i}}-V_{i, m j, \tau_{i}+k_{i}}}{M_{i, k_{i}}} .
$$


The "Put_Option" variable is defined as the probability that equity is negative:

$$
\begin{aligned}
\text { PutOption }_{i, k_{i}} & =\operatorname{prob}\left(E_{i, k_{i}}<0\right) \\
& =\Phi\left(\frac{\log V_{i, m j, \tau_{i}+k_{i}}-\log M_{i, k_{i}}}{\sqrt{\omega^{2}}}\right),
\end{aligned}
$$

where $\Phi(\cdot)$ is cumulative standard normal distribution function, and $\omega^{2}$ is an estimated variance defined in A ppendix B.

A s indicated in footnote 14 in the text, we also estimated the model with "Put_Option" using the par value of each mortgage, $\mathrm{V}_{\mathrm{i}}{ }^{*} \mathrm{r}_{\mathrm{i}}$ as defined in (11). When the put option is valued in this way,

$$
\text { Putoption }{ }_{i, k_{i}}^{*}=\Phi\left(\frac{\log V_{i, \tau_{i}}^{*}-\log M_{i, k_{i}}}{\sqrt{\omega^{2}}}\right) \text {, }
$$

the results reported in the text are unchanged.

\section{Appendix B: The Weighted Repeated Sales (WRS) House Price Index}

Housing price indices and their volatilities are estimated according to the three stage procedure suggested by Case and Shiller (1987) and modified by Quigley and V an O rder (1995). The model assumes that log price for ith house at time $t$ is given by

$$
\mathrm{P}_{\mathrm{it}}=\mathrm{I}_{\mathrm{t}}+\mathrm{H}_{\mathrm{it}}+\mathrm{N}_{\mathrm{it}}
$$

where $I_{t}$ is the logarithm of the regional housing price level, $H_{i t}$ is a Gaussian random walk, such that

$$
\begin{aligned}
& E\left[H_{i, t+k}-H_{i t}\right]=0, \\
& E\left[H_{i, t+k}-H_{i t}\right]^{2}=k \sigma_{\eta_{1}}^{2}+k^{2} \sigma_{\eta_{2}}^{2} ;
\end{aligned}
$$

and $\mathrm{N}_{\mathrm{it}}$ is white noise, such that

$$
\begin{aligned}
& \mathrm{E}\left[\mathrm{N}_{\mathrm{it}}\right]=0, \\
& \mathrm{E}\left[\mathrm{N}_{\mathrm{it}}\right]^{2}=\frac{1}{2} \sigma_{\nu}^{2} .
\end{aligned}
$$

The model is estimated on paired sales of owner occupied housing. In the first stage, the log price of the second sale minus the log price of the first sale is regressed on a set of dummy variables, one for each time period in the sample except the first period. The dummy variables have values of +1 for the quarter of the second sale, -1 for the quarter of the first sale, and zeros otherwise. (This follows Bailey, M uth, and N ourse (1963) exactly.)

In the second stage, the squared residuals $\left(\omega^{2}\right)$ from each observation in the first stage are regressed upon $\mathrm{k}$ and $\mathrm{k}^{2}$ :

$$
\omega^{2}=\mathrm{A}+\mathrm{Bk}+\mathrm{Ck}^{2},
$$

where $k$ is the interval between the first and second sale. The coefficients $A, B$, and $C$ are estimates of $\sigma_{\nu}^{2}, \sigma_{\eta_{1}}^{2}$ and $\sigma_{\eta_{2}}^{2}$ respectively.

In the third stage, the stage one regression is reestimated by $\mathrm{GLS}$ with weights $\left(\mathrm{A}+\mathrm{Bk}+\mathrm{Ck}^{2}\right)^{1 / 2}$. The estimated log price level difference $\left(\hat{I}_{t+k}-\hat{I}_{t}\right)$ is normally distributed with mean $\left(I_{t+k}-I_{t}\right)$, and variance $\left(\mathrm{k} \sigma_{\eta_{1}}^{2}+\mathrm{k}^{2} \sigma_{\eta_{2}}^{2}+\sigma_{\nu}^{2}\right)$. D enote $\mathrm{msa}_{\tau}=\exp \left(\hat{I}_{\tau}\right)$ as the estimated regional housing price index; then, in the $\mathrm{k}$ th quarter subsequent to purchase, $\log \left(\mathrm{msa}_{\tau+\mathrm{k}} / \mathrm{msa}_{\tau}\right)$ is normally distributed with mean $\left(\mathrm{I}_{\tau+\mathrm{k}}-\mathrm{I}_{\tau}\right)$ and variance $\left(\mathrm{k} \sigma_{\eta_{1}}^{2}+\mathrm{k}^{2} \sigma_{\eta_{2}}^{2}+\sigma_{\nu}^{2}\right)$.

$M$ eans and variances are estimated for each of 30 major MSA regions using samples of paired sales. There are about four million paired sales in the Freddie $M$ ac data base. 


\section{REFERENCES}

ARCHER, W. R ., AND D. C. LING (1993): "Pricing M ortgage-backed Securities: Integrating Optimal Call and Empirical Models of Prepayment," Journal of The American Real Estate and Urban E conomics Association, 21, 373-404.

ARCher., W. R., D. C. LING, AND G. A. MCGILl (1996): "The Effect of Income and Collateral Constraints on Residential M ortgage Terminations," Regional Science and Urban E conomics, 26, 235-261.

Bailey, M. J., R. F. M Uth, AND H. O. Nourse (1963): “A Regression M ethod for Real Estate Price Index Construction," J ournal of The American Statistical Association, 58, 933-942.

BLACK, F., AND M. S. SCHOLES (1973): "The Pricing of O ptions and Corporate Liabilities," Journal of Political Economy, 81, 637-654.

Brennan, M. J., AND E. S. Schwartz (1985): "D eterminants of GN M A M ortgage Prices," Journal of The American Real Estate and Urban E conomics Association, 13, 209-228.

Buser, S. A., AND P. H. Hendershott (1984): "Pricing Default Free M ortgages," Housing Finance Review, 3, 405-429.

CASE, K. E., AND R. J. ShILleR (1987): "Prices of Single-Family H omes Since 1970: N ew Indexes for Four Cities," New England Economic Review, September, 45-56.

COX, D. R., AND D. OAKES (1984): Analysis of Survival Data, M onographs on Statistics and A pplied Probability. London: Chapman and $\mathrm{H}$ all.

Cox, J. C., J. E. Ingersoll, ANd S. A. Ross (1985): "A Theory of the Term Structure of Interest Rates," Econometrica, 53, 385-467.

Cunningham, D. F., And P. H. Hendershott (1984): "Pricing FHA M ortgage Default Insurance," Housing Finance Review, 13, 373-392.

DENG, Y. (1997): "Mortgage Termination: An Empirical Hazard Model with Stochastic Term Structure," The Journal of Real E state Finance and E conomics, 14, 309-331.

Deng, Y., J. M. QUigley, AND R. VAN ORder (1996): "M ortgage D efault and Low Down-payment Loans: The Cost of Public Subsidy," Regional Science and Urban E conomics, 26, 263-285.

Dunn, K. B., AND J. J. M CCONnELL (1981): "V aluation of M ortgage-Backed Securities," The Journal of Finance, 36, 599-617.

Epperson, J. F., J. B. Kau, D. C. Keenan, And W. J. Muller III (1985): "Pricing Default Risk in M ortgages," J ournal of The American Real Estate and Urban E conomics Association, 13, 261-272.

Findley, M. C., AND D. R. CApozza (1977): "The Variable Rate Mortgage: An Option Theory Perspective," J ournal of Money, Credit and Banking, 9, 356-364.

Foster, C., ANd R. VAn Order (1984): "An Option-Based Model of Mortgage Default," Housing Finance Review, 3, 351-372.

- (1985): "FHA Terminations: A Prelude to Rational Mortgage Pricing," Journal of The American Real Estate and Urban E conomics Association, 13, 273-291.

Green, J., ANd J. B. Shoven (1986): "The Effect of Interest Rates on M ortgage Prepayments," Journal of M oney, Credit and Banking, 18, 41-50.

HAN, A., AND J. A. Hausman (1990): "Flexible Parametric Estimation of Duration and Competing Risk M odels," Journal of A pplied E conometrics, 5, 1-28.

HARDING, J. P. (1997): "Estimating Borrower Mobility from Observed Prepayments," Real Estate Economics, 25, 347-371.

Hendershott, P. H., AND R. VAN ORder (1987): "Pricing Mortgages: An Interpretation of the M odels and Results," Journal of Financial Services Research, 1, 77-111.

KaU, J . B., AND D. C. KeEnan (1995): "An O verview of the Option-Theoretic Pricing of M ortgages," J ournal of Housing Research, 6, 217-244.

- (1999): "Patterns of R ational D efault," Regional Science and Urban E conomics, 29, 765-785.

KaU, J. B., D. C. KeEnAN, AND T. KıM (1993): "Transaction Costs, Suboptimal Termination and D efault Probabilities," Journal of The American Real Estate and U rban Economics Association, 21, 247-263. 
Kau, J. B., D. C. Keenan, W. J. Muller, and J. F. Epperson (1992): “A Generalized Valuation M odel for Fixed-R ate R esidential M ortgages," J ournal of M oney, Credit and Banking, 24, 279-299. (1995): "The V aluation at Origination of Fixed R ate M ortgages with Default and Prepayment," The Journal of Real Estate Finance and E conomics, 11, 5-36.

MCCALL, B. P. (1996): "U nemployment Insurance Rules, Joblessness, and Part-Time Work," E conometrica, 64, 647-682.

MERTON, R. C. (1973): "Theory of Rational Option Pricing," Bell Journal of Economics and Management Science, 4, 141-183.

Quercia, R. G., And M. A. Stegman (1992): "Residential Mortgage Default: A Review of the Literature," Journal of Housing Research, 3, 341-379.

QUIGLEY, J. M . (1987): "Interest R ate V ariations, M ortgage Prepayments and H ousehold M obility," The Review of E conomics and Statistics, 69, 636-643.

Quigley, J. M., AND R. VAN ORDER (1990): "Efficiency in the Mortgage Market: The Borrower's Perspective," J ournal of The American Real Estate and Urban E conomics Association, 18, 237-252. (1995): "Explicit Tests of Contingent Claims M odels of M ortgage Default," The Journal of Real Estate Finance and E conomics, 11, 99-117.

SChWARTZ, E. S., AND W. N. Torous (1989): "Prepayment and the Valuation of Mortgage-Backed Securities," The Journal of Finance, 44, 375-392.

(1993): "M ortgage Prepayment and Default Decisions: a Poisson Regression A pproach," Journal of The American Real Estate and Urban E conomics Association, 21, 431-449.

Stanton, R . (1995): "R ational Prepayment and the V aluation of M ortgage-Backed Securities," The Review of Financial Studies, 8, 677-708.

SUEY OSHI, G. (1992): "Semiparametric Proportional H azards E stimation of Competing R isks M odels with Time-varying Covariates," Journal of E conometrics, 51, 25-58.

Titman, S., And W. N. TORous (1989): "V aluing Commercial M ortgages: A n Empirical Investigation of the Contingent Claims A pproach to Pricing R isky D ebt," The Journal of Finance, 44, 345-373.

VAndelL, K. D. (1993): "Handing Over the Keys: A Perspective on Mortgage Default Research," Journal of The American Real Estate and Urban E conomics Association, 21, 211-246.

YEZER, A. M., R. F. PHILliPS, AND R. P. TROSt (1994): "Bias in Estimates of Discrimination and D efault in M ortgage Lending: The Effects of Simultaneity and Self-Selection," The J ournal of Real E state F inance and E conomics, 9, 179-215. 